\title{
De blinddoek opzij : een mensenrechtenbenadering van geweld tegen vrouwen
}

Citation for published version (APA):

Boerefijn, I. (2006). De blinddoek opzij : een mensenrechtenbenadering van geweld tegen vrouwen. Maastricht University. https://doi.org/10.26481/spe.20061208ib

Document status and date:

Published: 08/12/2006

DOI:

10.26481/spe.20061208ib

Document Version:

Publisher's PDF, also known as Version of record

\section{Please check the document version of this publication:}

- A submitted manuscript is the version of the article upon submission and before peer-review. There can be important differences between the submitted version and the official published version of record.

People interested in the research are advised to contact the author for the final version of the publication, or visit the DOI to the publisher's website.

- The final author version and the galley proof are versions of the publication after peer review.

- The final published version features the final layout of the paper including the volume, issue and page numbers.

Link to publication

\footnotetext{
General rights rights.

- You may freely distribute the URL identifying the publication in the public portal. please follow below link for the End User Agreement:

www.umlib.nl/taverne-license

Take down policy

If you believe that this document breaches copyright please contact us at:

repository@maastrichtuniversity.nl

providing details and we will investigate your claim.
}

Copyright and moral rights for the publications made accessible in the public portal are retained by the authors and/or other copyright owners and it is a condition of accessing publications that users recognise and abide by the legal requirements associated with these

- Users may download and print one copy of any publication from the public portal for the purpose of private study or research.

- You may not further distribute the material or use it for any profit-making activity or commercial gain

If the publication is distributed under the terms of Article $25 \mathrm{fa}$ of the Dutch Copyright Act, indicated by the "Taverne" license above, 


\section{De blinddoek opzij}

Een mensenrechtenbenadering van geweld tegen vrouwen 


\section{Colofon}

Bustrontwerp en reallsate: Oce Eusiness Services, Universite Maostricht.

Afbeelding omslag: Vrowwe lustitia, Anton Lemmers (7003)

Nitr-code: 6 t 2

BSBN-10: $90-568-253 \times$

$156 N-93: 978 \cdot 90 \cdot 5681-259 \cdot 9$

Alle rechten woobehouden Niets wit dere witgave mag worden verveevoudigd opgesfagen in een geautomatiseerd gegevensbestand of openbad gemaokt, zonder voorafgawde schriftelijke toestemaming vall de auteur of uitgever. 


\section{De blinddoek opzij}

Een mensenrechtenbenadering van geweld tegen vrouwen

Rede

in verkorte vorm uitgesproken bij de aanvaarding van het ambt van bijzonder hoogleraar op de vierde opzij wisselleerstoel Macht en Strategie aan de Faculteit der Cultuur- en Maatschappijwetenschappen van de Universiteit Maastricht

op vrijdag 8 december 2006

door

mr. Ineke Boerefijn 

Mijnheer de Rector, zeer gewaardeerde toehoorders,

\section{Inleiding}

Elke woensdag demonstreren Koreaanse vrouwen voor de Japanse ambassade in Seoel. Het zijn vrouwen die in de Tweede Wereldooriog door Japanse soldaten seksueel zijn misbruikt als "troostmeisjes". Naar schatting zijn ongeveer 200.000 vrouwen uit verschillende Aziatische landen en Nederland slachtoffer geworden van deze vorm van seksuele slavernij. Velen van hen zijn inmiddels niet meer in leven; de overlevenden zijn nu in de tachtig. Tot op de dag van vandaag heeft de Japanse regering nog steeds niet volledig haar juridische verantwoordelijkheid erkend en is de kwestie van schadevergoeding voor de betrokken vrouwen niet naar hun tevredenheid opgelost'. Het is veelzeggend voor de ernst van hum leed dat deze vrouwen zich 60 jaar na het einde van de oorlog niet neerleggen bij deze situatie.

Verkrachting in oorlogstijd komt nog steeds op grote schaal voor, evenals gedwongen abortussen en gedwongen zwangerschappen denk aan Joegoslavië, Rwanda en Soedan, waar verkrachting van vrouwen doelbewust is ingezet als methode om bevolkingsgroepen ernstig leed toe te brengen, te vernederen en de samenstelling van de bevolking te manipuleren.

Recent onderzoek bevestigt dat de politie in Nederland jaarlijks ongeveer 57.000 gevallen van huiselijk geweld registreert. De geregistreerde gevallen van huiselijk geweld vertegenwoordigen slechts $12 \%$ van alle gevallen van huiselijk geweld. Dat betekent dus dat het in totaal om bijna een half miljoen gevallen gaat. Van alle slachtoffers is ruim drie kwart vrouw. Onder slachtoffers van seksueel huiselijk geweld is dat percentage nog hoger, namelijk ruim $84 \%^{2}$.

Het lijkt waarschijnlijk zonneklaar dat het thier om zo erinstige zaken gaat dat het wel schendingen van de rechten van de mens moeten zijn. Anno 2006 is dat inderdaad onomstreden, maar het is nog maar kort geleden dat daar heel anders over werd gedacht. 
Seksueel geweld in oorlogstijd is lang niet erkend als schending wan de rechten van de mens; het was naar voor de betrokken vrouwen en men zag het wel als een aantasting van haar eer, maar niet als een schending van een recht. Ook zag men de verkrachtingen niet als een echte oorlogshandeling in naam van de staat; maar als cen privé-handeling van de pleger. De uitspraken vam het Tokio Tribunaal en het Neurenberg Tribunaal maken geen expliciete vermelding van verkrachting ${ }^{3}$.

Vrouwenmishandeling in de priwé-sfeer is langgezien als een probleem van de individuele vrouw, niet als een maatschappelijk probleem. Het ging niet om mishandeling door de overheid, en dus niet om mensenrechtenschendingen. De rechten van de mens waren immers bedoeld om het individu te beschermen tegen machtsmisbruik door de overheid. Wat achter de voordeur gebeurde was juist geen zaak van de overheid ${ }^{4}$.

Verontwaardiging over vrouwenmishandeling zagen en zien we wel als het gaat om cultureel bepaalde vormen van geweld tegen wrouwen. Er is in Nederland - terecht uiteraard - veel aandacht voor praktijken als genitale verminking en eerwraak onder allochtonen, maar de aandacht voor andere vormen wan vrouwenmishandeling, die weel vaker voorkomen, blijt daarbij sterk achter. Geweld tegen vrouwen is een ernstig en omvangrijk probleem. Het komt overal voor, niet alleen in ontwikkelingslanden, achterstandsbuurten en onder allochtonen.

Wat ik vandaag wil doen, is u laten zien dat geweld tegen vrouwen een schending van de rechten van de mens is, maar ook wat die rechten kunnen betekenen yoor de aanpak wan het probleem. Ik zal eerst ingaan op de vraag wat "mensenrechten van wrouwen" zijn. Op het eerste gezicht is dat een merkwalardige uitdrukking, vrouwen zijn immers ook mensen. Vrouwe Justitia draagt niet voor niets een blinddoek, zij symboliseert dat ledereen gelijk is voor de wet en de rechter. Ook is het de vraag of het wel verstandig is te benadrukken dat vrouwen aparte aandacht nodig hebben, en of dat hen dan niet in een slachtofferrol drukt. Daarna zal lk ingaan op de manier waarop nu in het internationale recht tegen geweld tegen vrouwen wordt aangekeken. Ik neem de ontwikkelingen van de afgelopen jaren op hoofdlijnen met $u$ door. Ik zal bespreken wat internationale instanties die gedrag van staten beoordelen, hebben gedaan om invulling te geven aan de idee dat geweid tegen vrouwen een schending is van de rechten van de mens, en hoe zij omgaan met de verschillende verplichtingen van de overheid. 


\section{Mensenrechten van vrouwem}

"Alle rechten van de mens zijn universeel, ondeelbaar en onderling afhankelijk." Aldus luidt de Verklaring van Wenen die de Wereldconferentie Mensenrechten in Wenen in 1993 aannam ${ }^{5}$. Als alle rechten van de mens universeel zijn spreken over "mensenrechten van vrouwen". Dat zou suggereren dat zij andere rechten hebben dan mannen. Mensenrechtenverdragen en -verklaringen beogen "een ieder" te beschermen en benadrukken dat discriminatie wegens onder meer ras, huidskleur, godsdienst en geslacht verboden is. Maar om "een ieder" effectlef te beschermen, kan het nodig zijn rekening te houden met relevante verschillen. Het internationale recht inzake de rechten van de mens gaat uit van een mannelijk wereldbeeld en neemt onvoldoende in acht dat wat goed is voor mannen, niet in alle gevallen goed is voor vrouwen ${ }^{6}$.

Delegaties naar internationale organen die de mormen opstelden, bestonden in grote meerderheid uit mannen. Internationale instanties die toezicht houden op de naleving van mensenrechteninstrumenten bestaan hoofdzakelijk uit mannen. Het is een feit dat de aanwezigheid van vrouwen nodig is om het vrouwenperspectief in te brengen, ondanks het feit dat er mannen zijn die dit goed kunnen, en er vrouwen zijn die dat niet kunnen.

Deondervertegenwoordiging vanvrouwen bij het makenvan nationaal en internationaal beleid leidde ertoe dat het vooral mannen waren die onder woorden brachten wat de rechten van de mens waren. Er was daarom vooral aandacht voor bescherming tegen handelingen waarvan zij bang waren dat die hen zouden overkomen. Met andere woorden, de rechten van de mens in algemene mensenrechteninstrumenten, zoals de Universele Verklaring van de Rechten wan de Mens, zijn niet geformuleerd en geinterpreteerd op een manier die rekening houdt met de "verhalen van vrouwen"t.

Wat zijn dan relevante verschillen tussen mannen en vrouwen? De rechten van de mens beschermen in de eerste plats het individu tegen machtsmisbruik door de overheid. Dat betekent dat zij mensen vooral bescherming bieden in het openbare leven, dat is immers het terrein waarop de overheid zich begeeft. Die bescherrning is er uiteraard voor mannen en vrouwen. Dat betekent echter nog niet dat vrouwen en 
mannen op gelijke manier door de rechten van de mens beschermd worden. In zijn algemeenheid kunnen we stellen dat het leven van mannen zich meer in de openbare sfeer afspeelt en dat van vrouwen in de privé-sfeer. Dat betekent dat vrouwen eerder in de privé-sfeer iets zal overkomen dan in de openbare sfeer. Met andere woorden, als vrouwen mishandeld worden, is dat eerder door hun partner of een familielid, dan door de overheid. Als de rechten van de mens dus alleen bescherming bleden tegen handelingen wan de overheid, en niet tegen die van privépersonen, hebben vrouwen er minder aan.

Er lijkt een zekere vrees te bestaan dat het begrip rechten van de mens verwatert als handelingen in de privé-sfeer ook als mensenrechtenschendingen worden gekwalificeerd. De opvatting dat bepaalde handelingen de aandacht van de rechten wan de mens verdienen bestaat echter al lang. Slavernij bijwoorbeeld is al in een ver verleden erkend als een schending van de rechten van de mens, terwijl het hoofdzakelijk individuen zijn die anderen in slavernij, of slavernijachtige omstandigheden houden ${ }^{8}$. Rassendiscriminatie is al lang erkend als schending van de rechten van de mens $^{9}$, terwijl ook dat voornamelijk door privéa-personen gebeurt.

Het negeren van geweld tegen vrouwen komt niet uitsluitend amdat eronderscheid tussen de privé-sfeer en openbare ruimte wordt gemaakt, het feit dat het geweld vrouwen trof speelde eveneens een rol. Seksuele misdrijven waar alleen vrouwen het slachtoffer wan waren, werden niet gezien als mensenrechtenschendingen, ook al deden ze in ernst niet onder voor andere vormen van marteling.

Een perspectief dat rekening houdt met de verhalen van vrouwen, erkent dat het recht op leven ook betekent dat familieleden vrouwen en meisjes niet mogen doden als zij menen dat zij de eer van de familie hebben aangetast; dat hun recht gevrijwaard te zijn van mishandeling en hun recht op gezondheid ook inhoudt dat niet in hun genitalien wordt gesneden ondat de traditie dat vereist: dat hun recht op werk ook inhoudt dat zij op de werkplek niet worden lastiggevallen door hun collega's, en dat verkrachting in oorlogstijd als even verwerpelijk wordt beschouwd als andere vormen van marteling. Het privé-leven verdient uiteraard respect, maar dat mag er niet toe leiden dat het persoonlijke onzichtbaar is ${ }^{10}$. De overheid heeft daarom een plicht niet alleen bescherming te bieden tegen schendingen van de rechten van de mens in de openbare sfeer, maar ook tegen schendingen in de privé-sfeer. 
In algemene mensenrechteninstrumenten ontbreekt het perspectief van vrouwen. linstrumenten als de Universele Verklaring van de Rechten van de Mens formuleren de rechter opeen neutrale manier, in die zin dat ze voor een leder gelden, mannen en vrouwen, kinderen en volwassenen, witte en gekleurde mensen, gezonde mensen en mensen met een handicap. In de praktijk bleek dat dit onvoldoende bescherming bood. Een reeks verklaringen en verdragen kwam tot stand, met als doel betere bescherming te bieden tegen discriminatie wegens ras, discriminatie van vrouwen, voor de bescherming van de rechten van het kind en, als meest recente voorbeeld, mensen met een handicap.

Deze uitwerking in specifieke verdragen dient een aantal doelen. Het Vrouwenverdrag geeft een concretere invulling aan het recht van vrouwen op gelijke behandeling dan is gedaan in de algemene mensenrechtenverdragen. Daarnaast is met de instelling van een afzonderlijk comité dat toezicht houdt op de naleving van het Vrouwenverdrag gewaarborgd dat het toezicht op de naleving van deze rechten in de praktijk in handen is van deskundigen op het terrein van discriminatie van vrouwen.

Het is steeds de bedoeling geweest dat de algemene mensenrechtenverdragen de positie van vrouwen beschermen. Het bestaan van een speciaal instrument is geen legitimatie voor het negeren van de specifieke problemen van vrouwen door organen die zich met mensenrechten in het algemeen bezighouden. In de praktijk bleef die aandacht echter achter, wat tot toenemende kritiek leidde. Vrouwenorganisaties maakten duidelijk dat de rechten van vrouwen gemarginaliseerd waren en dat een omslag in het denken noodzakelijk was ${ }^{11}$.

De lobby van de vrouwenorganis atles was intensief en succesvol. Met name sinds de jaren 'go hebben zich grote veranderingen voorgedaan. Het begon met het Internationale Decennium voor Vrouwen (19751985), dat onder meer resulteerde in de erkenning van geweld tegen vrouwen als een mensenrechtenkwestie. De campagne "16 dagen actie tegen geweld tegen vrouwen', gevoerd in 1991, maakte de verbinding tussen geweld tegen vrouwen en de rechten van de mens. De 16 dagen verbonden 25 november - de internationale dag over geweld tegen vrouwen - en to december - de internationale dag van de rechten van de mens. Het is een mooi toeval dat de datum van mijn oratie, 8 december, tussen deze data valt. 
Voorafgaand aan en tijdens de Wereldconferentie over de rechten van de mens (Wenen, 1993) en de Vierde Wereldvrouwenconferentie (Peking, 1994) bereikte de lobby een hoogtepunt. "Vrouwenrechten zijn mensenrechter" was een slogan waar niemand ombeen kon, en de term mensenrechten van wrouwen raakte ingeburgerd. Hiermee maakten vrouwven duidelijk dat zij niet een aparte status benadrukten en niet vroegen om andere rechten of meer rechten, maar dat het noodzakelijk is dat rekening wordt gehouden met hun ervaringen. Zonder dat, hebben zij niet het volledig genot van de rechten van de mens ${ }^{12}$. Een andere term die zijn intrede deed in internationale documenten, is de term "gender". Daarvoor bestaat geen goede Nederlandse vertaling al gebruiken we soms "seksespecifiek". Het gebruik van de term gender in relatie tot discriminatie geeft aan dat het miet alleen gaat om biologische verschillen tussen vrouwen en mannen, maar ook om de sociale rollen die niet per se verbonden zijn met de biologische sekse ${ }^{13}$. Omdat mijn verhaal over geweld tegen vrouwen gaat, gebruik ik liever de uitdrukking "perspectief van vrouwen."

Het nut van het zogenoemde tweesporenbeleid, dat voorziet in een algemeen mensenrechteninstrumentarium naast een specifiek vrouweninstrumentarium, is in de Slotverklaringen wan Wenen en Peking bevestigd. De Verklaring van Wenen erkende en veroordeelde geweld tegen vrouwen in all zijn vormen, in de privé-sfeer en in de openbare sfeer, als schending van de rechten van de mens ${ }^{14}$ en stelde dat de mensenrechten van vrouwen dienen te worden geintegreerd in alle onderdelen van de Verenigde Naties ${ }^{15}$. Tegelijkertijd riep de Verklaring op tot instelling van een Speciale Rapporteur inzake Geweid tegen Vrouwen, terwijl de Commissie inzake de Positie van de Vrouw en het Comité inzake de Uitbanning van Discriminatie van Vrouwen werden opgeroepen het toezichtmechanisme bij het VN Vrouwenverdrag te versterken door het opstellen wan een protocol met een individueel klachtrecht 16 .

Wat vrouwen dus met succes hebbengeclaimd is dat het internationale recht inzake de rechten van de mens de bescherming biedt die hen als mens toekomt. Dankzij sterke lobbies door vrouwenorganisaties is het thema geweld tegen vrouwen op de agenda gekomen; het is daar nu niet meer weg te denken. 
We zien in de praktijk dat er stappen vooruit gezet zijn. VN verdragscomités hebben in algemene aambevelingen aangegeven hoe zij de verhalen wan vrouwen in hun werk kunnen honoreren, en elk comité besteedt aandacht aan geweld tegen vrouwen ${ }^{17}$; het Joegoslavie Tribunaal en het Rwanda Tribunaal hebben aorlogsmisdadigers veroordeeld voor verkrachting, het internationale Strafhof heeft een afdeling waar medewerkers zijn gespecialiseerd in het omgaan met slachtoffers van seksueel geweld die getuigen in processen. Een andere belangrijke erkenning dat seksueel geweld in oorlogstijd een grove schending is van de mensenrechten van vrouwen vinden we in de baanbrekende resolutie 1325 van de Veiligheidsraad van de Verenigde Naties. De Raad roept alle partijen in een gewapend conflict op speciale maatregelen te treffen om vrouwen en meisjes te beschermen tegen seksespecifiek geweld, in het bijzonder verkrachting en andere vormen van seksueel misbruik en dringt erop aan dat misdrijven tegen de menselijkheid en oorlogsmisdaden, waaronder seksueel en ander geweld tegen vrouwen en meisjes, waar mogelijk, worden uitgesloten van amnestieregelingen 18 .

Jaarlijks staat het thema op de agenda van politieke organen zoals (eerst de Commissie, nu) de Raad voor de Rechten van de Mens en de Algemene Vergadering van de Verenigde Naties ${ }^{19}$. Wat schadelijke traditionele praktijken betreft, die doorgaans diep geworteld zijn in cultuur, is op internationaal niveau veel discussie over wat wel en niet tot geweld tegen vrouwen moet worden gerekend. vroege en gedwongen huwelijken bijwoorbeeld, zijn zeer schadelijk woor jonge meisjes 20 , maar dit te erkennen en streven naar een verbod is voor veel landen onbespreekbaar. Hetzelfde geldt voor eermoord, waar een (doorgaans minderjarig) familielid een vrouw doodt omdat zij de eer van de familie heeft beschadigd met haar gedrag. Sommige landen houden vol dat dit niet anders is dan een crime passionel waarvoor men in sommige andere landen een beroep kan doen op noodweer ${ }^{21}$. De positieve rol van Nederland is hier het vermelden waard; al jaren is Nederland de indiener van de resolutle over geweld tegen vrouwen en maakt ons land zich sterk voor veroordeling van geweld tegen vrouwen. Op 22 november $\mathrm{jl}$. nam de Algemene vergadering unaniem een resolutie aan, die alle staten oproept hun inspanningen gericht op het uitbannen van alle vormen van geweld tegen vrouwen uit te breiden ${ }^{22}$. 


\section{Geweld tegen vrouwen als schending van de rechtemens}

Wie begint met de bestudering van internationale normen over geweld tegen vrouwen neemt uiteraard eerst het VN Vrouwenverdrag, dat in 1979 is aangenomen, onder de loep. Daar zoeken we echter tevergeefs naar een bepaling over het recht op veiligheid van persoon en een verbod van mishandeling. In de tijd dat deze tekst werd opgesteld, kon geen overeenstemming bereikt worden over de opname van een dergelijke bepaling ${ }^{23}$. Hier zien we hoe belangrijk het is dat een internationalle commissie van onafhankelijke deskundigen op het gebied van discriminatie van vrouwen dit internationale instrument interpreteert. In Algemene Aanbeveling No. 19 uit 1992 bevestigde het Comité inzake de Uitbanning van Discriminatie van Vrouwen dat geweld tegen wrouwen een worm van discriminatie is en daarmee binnen zijn werkterrein valt ${ }^{24}$. Dat maakt het ontbreken wan een specifieke bepaling grotendeels goed. Het onderwerp is een vast thema in het werk van het comite in het kader van de rapportageprocedure, en vrouwenmishandeling is inmiddels woorwerp geweest van een individuele klacht. Op de uitspraak in deze klacht kom ik straks terug.

In 1993 nam de Algemene Vergadering van de Verenigde Naties de Verklaring inzake Geweld tegen Vrouwen aan ${ }^{25}$; in $1994 \mathrm{kwam}$ in het kader wan de Organisatie van Amerikaanse Staten het Inter-Amerikaanse Verdrag inzake de Uitbanning van Geweld tegen Vrouwen tot stand, waarin een recht gevrijwaard te zijn van geweld is opgenomen ${ }^{26}$. Tot slot verdient vermelding dat aan het Afrikaanse Handvest inzake de Rechten van de Mens en Volken recent een facultatief protocol is toegevoegd (bekend als het Maputo Protocol) over de rechten van vrouwen waarvan geweld tegen wrouwen een prominent onderdeel uitmaakt ${ }^{27}$. Elk instrument heeft een aantal unieke kenmerken. Zo is artikel 4 van de VN Verklaring het meest expliciet in de vaststelling dat staten geen enkele gewoonte, traditie of religieuze overweging mogen inroepen voor het niet naleven van hun verplichtingen onder de Verklaring. Het Verdrag van de OAS formuleert als enige instrument "het recht gevrijwalard te zijn van geweld" (artikel 3 ) en is het meest gedetailleerd in de omschrijving van rechten en plichten. Het Maputo Protocol is het eerste bindende internationale instrument dat bepaait dat vrouwen het recht hebben op toegang tot abortus als verkrachting of incest tot zwangerschap heeft geleld (artikel $14(2)(c))^{28}$ 
De meest gebruikte definitie van geweld tegen vrouwen luidt:

elke doad van geweld op basis wan gender die resulteert of kan resulteren in lichamelijke, seksuele of psychologische schade aam of lijden van wrouwen, met inbegrip van de dreiging van dergelijke gewelddaden, dwang of willekeurige wrijheids berowing, ongeacht of dit plaatswindt in het openbaar of in de prive-sfeer. 29

De verschillende instrumenten noemen vervolgens een aantal vormen van geweld die in leder geval binnen de reikwijdte van de definitie vallen. Gebruikelijk is een onderwerdeling in drie sferen: geweld door de staat, geweld in de openbare ruimte en geweld in de privé-sfeer. Wat geweld door of namens de staat betreft, benadrukken het inter-Amerikaanse Verdrag en de VN Verklaring dat dat ongeacht de plaats van handeling is: geweld door de staat kan dus ook plaatsvinden in de woning van de vrou $w_{n}$ op haar werkplek of op straat. De identiteit van de pleger is doorslaggevend, niet de plaats van handeling. Geweld in de openbare sfeer doelt op handelingen als verkrachiting op straat, seksuele intimidatie op de werkplek, in gezondheids- en onderwijsinstellingen, wrouwenhandei en gedwongen prostitutie. Tenslotte bestrijkt de definitie datgene wat in Nederland bekend staat als "huiselijk geweld". Het gaat dan om geweld in het gezin, binnen een relatie, ongeacht of de pleger een huishouden deelt of heeft gedleeld met de vrouw. Het gaat om vergrijpen als moord, doodslag, verkrachting, mishandeling, seksueel misbruik, genitale verminking en andere schadelijke traditionele praktijken.

Bij geweld tegen vrouwen zijn diverse rechten van de mens in het geding. Waar vrouwen gedood worden omdat zij als vrouw de familieeer zouden hebben beschadigd, is hun recht op leven geschonden. Van vrouwen die door een gevangenisbewarder tijdens hun detertie worden verkracht, is het recht gevrijwaard te zijn van marteling geschonden ${ }^{30}$. Als hun daarna adequate medische zorg wordt onthouden, is thun recht op gezondheid in het geding. Waar familieleden of de echtgenoot een vrouw in huis opsluiten beperken zij haar recht op wrijheid, evenals. haar recht op gelijkheid in het gezin. Als de staat onvoldoende presteert bij de opsporing en berechting vain geweld tegen vrouwen, is het recht op gelijkheid voor de wet en gelijke bescherming door de wet geschonden. 
De gevolgen van geweld zifn enorm en kunnen op zichzelf ook in termen van mensenrechten worden omschreven. Vrouwen die slachtoffer zijin van geweld, nemen minder makkelijk deel aan het openbare leven. Vrouwen die op jonge leeftijd - soms op de leeftijd van 8 jaar - gedwongen worden te trouwen, verlaten school voortijdig en zijn vervolgens niet in de gelegenheid door betaalde arbeid in hun eigen bestaan te voorzien.

De oorzaak wan geweid tegen wrouwen ligt in de structurele machtsongelijkheid van mannen en vrouwen, bovendien draagt geweld tegen vrouwen bij aam het instandhouden van ongelijkheid ${ }^{31}$. Bij het woorko. men en bestrijden van geweld dient dit gegeven dan ook het uitgangspunt te zijn. Omdat geweld tegen vrouwen een schending is van de rechten van de mens, dient de bestrijding ervan te zijn gebaseerd op het menserirechteninstrumentarium. De algemene instrumenten zouden de basis moeten wormen voor de invulling van de relevante rechten en verplichtingen. In thet nu volgende deel zal ik met name daar op ingaan.

\section{Rechten van de mens en de daarmee corresponderende verplichtingen}

Internationale mensenrechteninstrumenten kennen verschillende soorten verplichtingen voor staten ${ }^{32}$. In de eerste plats mogen staten zelf geen rechten schenden. Dit wordt wel de verplichting te respecteren genoemd. Indien overheden deze verplichting schenden, zijn zij daarvoor rechtstreeks aansprakelijk en kunnen ze voor internationale instanties ter verantwoording worden geroepen. In de tweede plaats hebben zij een verantwoordelijkheid te verzekeren dat niet-statelijke actoren, zoals individuen en ondernemingen, rechten van individuen niet aantasten. Deze verplichting kennen we als de verplichting te beschermen. Aangezien geweld in de privé-sfeer de meest voorkomende vorm van geweld tegen vrouwen is, is de verplichting te beschermen uitermate relevant.

Juristen gebruiken graag modelen om te toetsen of een staat aan ziljn werplichting de rechten van de mens te beschermen heeft voldaan Omdat aansprakelijkheld van de staat voor gedrag van individuen niet vanzelfsprekend is, is een toets ontwikkeld voor het vaststellen of de overheid kan worden aangesproken op een handeling van een burger Deze toets staat bekend met een Engelse term, te weten de "due diligence" toets. Helaas is hiervoor (nog) geen Nederlandse term bedacht Ik gebruik hier de term "met gepaste inzet". Het is een verplichting voor 
de overheid alle matregelen te treffen die, gelet op de omstandigheden, mogen worden verwacht teneinde schendingen te voorkomen en adequaat op te treden in geval van een schending door te onderzoeken wie verantwoordelijk is, en die persoon vervolgens te berechten en te bestraffer ${ }^{33}$.

De term "met gepaste inzet" is in de mensenrechtenjurisprudentie geintroduceerd door het Inter-Amerikaanse Hof voor de Rechten van de Mens. De zaak Velazquez Rodriguez tegen Honduras betrof een gedwongen verdwijning die niet direct aan de overheid kon worden toegeschreven. Het Inter-Amerikaanse Hof redeneerde dat er toch internationale aansprakelijkheid van de staat kon zijn, niet vanwege de handeling zelf, maar vanwege het nalaten gepaste inzet te betrachten om de schending te voorkomen of erop te reageren 34 .

In de discussies over geweld tegen vrouwen zien we de term "met gepaste inzet" veelvuldig. Hij is opgenomen in de VN Verklaring inzake Geweld tegen Vrouwen ${ }^{35}$ en het inter-Amerikaanse Verdrag inzake Geweld tegen Vrouwen ${ }^{36}$; de Speciale Rapporteur inzake Geweld tegen Vrouwen heeft haar rapport van 2006 in zijn geheel gewijd aan de invulling van het begrip "met gepaste inzet"37.

Hier vallen een aantal dingen op. De term "met gepaste inzet" wordt nu gebruikt om inhoudelijke invulling aan verplichtingen van staten te geven, alsmede om het niveau van de inspanning van de staat, zowel voor zijn eigen handelingen als voor handelingen van privé-personen, te beoordelen. De term "met gepaste inzet" is daardoor een containerbegrip geworden, wat de duidelijkheid bepaald niet bevordert. Mijn bezwaren daartegen zijn tweeledig. in de eerste plaats worden de verplichtingen van staten om bepaalde maatregelen te treffen onvoldoende gebaseerd op de in verdragen erkende rechten en de interpretatie daarvan. In de tweede plaats miskent dit dat veel verplichtingen onder verdragen verder strekkende verplichtingen zijn dan een verplichting om met gepaste inzet te handelen, met name waar het gaat om handelingen van de staat en zijn functionarissen. I $\mathrm{k}$ wil in mijn toekomstig onderzoek deze toets dan ook aan een kritisch onderzoek onderwerpen en doe daarvoor hier een woorzet.

Ik stel voor de twee aspecten, de zoektocht naar de inhoudelijke invulling van het recht gevrijwaard te zijn van geweld en de daarbij beho- 
rende verplichtingen te onderscheiden van het toetsen van het niveau van inspanning door de overheid.

Zoals gezegd, zijn bij geweld tegen vrouwen diverse rechten van de mens in het geding. Bij het invullen van de inhoudelijke verplichtingen die staten hebben, is het zinvol aansluiting te zoeken bij bestaande formuleringen in verdragen en de interpretaties daarvan door internationale toezichthoudende instanties. Wat we nu zien, is dat onderzoekers en de VN Specialle Rapporteur een breed scala verplichtingen van de overheid kwalificeren als verplichtingen die de overheid "met gepaste inzet" moet verwulten, ongeacht de juridische basis voor die verplichting. Bij het toetsen of de staat zich voldoende heeft ingespannen, diemen we te onderzoeken of hij heeft voldaan aan de verplichtingen die hij heeft onder verschillende verdragen. Daarbij maakt het verschil of die verdragen de staat concreet opdragen iets te doen of juist na te laten, of dat we willen bezien of de staat ook verantwoordelijk is voor het ged rag van een prive-persoon. In het eerste geval geldt onder internationaal recht dat de staat internationale aansprakelijkheid draagt voor handelingen van zijn eigen functionarissen, indien er sprake is wan een onrechtmatige handeling die in strijd is met het internationale recht (internationally wrongful act), zelfs als de functionaris zijn bevoegdheden overschrijdt of in strijd met zijn instructies heeft gehandeld ${ }^{38}$. De staat kan dan in dat geval niet ter rechtvaardiging aanvoeren dat hij "met gepaste inzet" heeft gehandeld. Waar we willen onderzoeken of de staat verantwoordelijk kan worden gehouden voor handelingen van privé-personen, gebruiken we de test of de staat "met gepaste inzet" heeft gehandeld.

Coherente interpretatie van internationaal beschermde rechten van de mens bevordert de effectiviteit van de toezichthoudende organen. De verschillende deskundigen, zoals de verdragscomités en de Speciale Rapporteurs, kunnen elkaars werk versterken door staten op internationaal niveau aan te spreken op hun verplichtingen. Dat draagt bij aan een betere bevordering en bescherming van de rechten van de mens.

Als de Speciale Rapporteur en andere deskundigen zouden aansluiten bij Jurisprudentie van de regionale mensenrechtenhoven en VN verdragscomités zouden zij onderstrepen dat hun werk de "mensenrechten wan vrouwen" betreft. Als zij die interpretaties verder uitwerken en preciseren waar nodig woor hun specifieke werkterrein, dragen zij bij aan een interpretatie van de rechten van de mens die ook voor vrouwen effectie- 
ve garanties biedt. Bovendien kan een dergelijke werkwijze bevorderen dat de betreffende comités en mensenrechtenhoven deze aanvillingen en aanscherpingen in hun interpretaties overnemen. Dat zou een mooie kruisbestuiving zijn waarmee we de discussies over geweld tegen vrouwen, zowel geweld door de staat alls geweld door prive-personen, integreren in de discussie over de naleving van de rechten van de mens.

Ik kan hier onmogelijk ingaan op alle voor geweld tegen vrouwen relevante rechten. Een van de doelen die ik mijzelf woor de periode van mijn aanstelling heb gesteld, is te onderzoeken op welke wijze de interpretatie van de relevante mensenrechten kan bijdragen aan de invulling van het recht gevrijwaard te zijn van geweld. In mijn onderzoek wil ik proberen inzicht te verschaffen in de toepassing van door mensenrechtenorganen ontwikkelde concepten en interpretaties op geweld tegen vrouwen, en hoe bestaande interpretaties beter kunnen worden ingevuld vanuit het perspectief van vrouwen. Met andere woorden: ik wil de twee sporen, het algemene mensenrechtenspoor en het vrouwenspoor dichter bij elkaar brengen. Een van de vragen die ik in mijn onderzoek wil beantwoorden, is of bestaande rechten inderdaad woldoende bescherming tegen geweld bieden, en dat het perspectief van vrouwen tot zijn recht kan komen, of dat het nodig is om op internationaal niveau te streven naar een nieuw bindend instrument waarin een recht gevrijwaard te zijn van geweld is gegarandeerd, en waarin het hele scala aan verplichtingen is uitgewerkt ${ }^{39}$.

\section{De rechten van de mens als basis voor de invulling van het recht gevrijwaard te zijn van geweld}

Ik gebruik een concreet voorbeeld uit het rapport van de Speciale Rapporteur inzake Geweld tegen Vrouwen om te illustreren wat ik bedoel. Zij onderscheidt de verplichting "met gepaste inzet bescherming te bieden"' en omschrijft deze als een verplichting voor de staat te verzekeren dat slachtoffers of potentiele slachtoffers van geweld toegang tot de rechter, gezondheidszorg en hulpverlening hebben.

Wat ik zou willen zien, is in de eerste plaats een andere formulering. namelijk in termen van een individueel recht, wat benadrukt dat het gat om een fundamenteel recht, dat reeds is erkend in internationale instrumenten. Een ieder die meent slachtoffer te zijn van een schending van de rechten van de mens heeft het recht op een effectief rechtsmiddel. Elk 
mensenrechtenverdrag bevat een dergelijk recht ${ }^{40}$. Indien geen passend rechtsmiddel beschikbaalr is, schendt de staat zijn verdragsverplichting. en kan daarvoor intermationaal aansprakelijk worden gehouden.

Om vast te stellen wat in concrete gevallen een effectief rechtsmiddel inhoudt, kunnen we de omvangrijke jurisprudentie van internationale instanties daarover onderzoeken. Rechtsmiddelen moeten toegankelijk en effectief zijn, en waar nodig aangepast aan de kwetsbare positie van slachtoffers. Er dienen toegankelijke klachtprocedures te zijn. Klachten dienen onmiddellijk, grondig en effectief te worden onderzocht door onafhankelijke en on partijdige instellingen. Het tekortschieten in het onderzoeken van schendingen kan op zichzelf een schending van het recht op een rechtsmiddel opleveren ${ }^{41}$. Het initiatief voor onderzoek naar schendingen dient bij de staat te liggen en moet op serieuze wijze wor den uitgevoerd 42 . Het recht gevrijwalard te zijn van marteling omvat niet alleen inhoudelijke, maar ook procedurele verplichtingen. Wil de garantie van dit recht effectief zijn, dan moet een grondig en effectief onderzoek plaatswinden dat kan leiden tot het vaststellen wie verantwoordelijk is, en tot berechting en bestraffing ${ }^{43}$. Een effectief rechtsmiddel kan nopen tot de rehabilitatie wan het slachtoffer, wat toegang tot medische en/of psychische hulpverlering kan inhouden.

Deze eisen gelden voor rechtsmiddelen in het algemeen. Deskundigen zoals de Speciale Rapporteur kunnen specificeren aan welke voorwaarden rechtsmiddelen dienen te voldoen om effectieve garanties te bleden aan vrouwen die met geweld te maken hebben, door bijvoorbeeld het belang van deskundigheidsbevordering van leden wan de rechterlijke macht te benadrukken.

Mw. Ertürk, de Speciale Rapporteur, spreekt in verband met de ver= plichting te bescherming te bieden ook wan een verplichting toegang tot de gezondheidszorg te verlenen. Het internationale recht kent ook een recht op gezondheid, wat zij als zodanig had kunnen noemen. Dit recht is door het Comite inzake Economische, Sociale en Culturele Rechten ingewuld in een algemene aanbeveling, en Mw. Ertürk zou het werk van dit Comité goed kumnen gebruiken als zij verder verfijnt welke specifieke maatregelen staten moeten treffen ten behoeve van slachtoffers van geweld. Zij zou kunnen aangeven dat faciliteiten voor gezondheidszorg daadwerkelijk beschikbaar dienen te zijn, dat wil zeggen, voldoende in aantal, met gespecialiseerd personeel, toegesneden op de opvang 
van en hulpverlening aan mishandelde vrouwen. Faciliteiten dienen toegankelijk te zijn. Er mag geen discriminatie plaatsvinden, ze moeten toegankelijk zijn ook woor de meest kwetsbare groepen, zoals vroumen met een handicap, vuchtelingenvrouwen, oudere vrouwen, plattelandsvrouwen, vrouwen met HIV/AIDS en vrouwen zonder geldige werblijfsvergunning. Ze dienen fysiek toegankelijk te zijn, dat wil zeggen op een veilige wijze te bereiken, en een veilig werblijf te garanderen. Ze dienen ook economisch beschikbaar te ziln; vrouwen die niet in staat zijn een eigen bijdrage te betalen mogen niet worden geweerd. Er dient toegang tot informatie te zijn, toegankelijkheid houdt in het recht informatie over opvang en hulpverlening te verspreiden en te ontvangen, met dien verstande dat het recht op toegang tot informatie niet betekent dat de vertrouwelijkheid van de gegevens van de betrokkenen wordt geschonden. Verder dienen faciliteiten aan kwaliteitseisen te voldoen, zoals de beschikbaarheid van schoon drinkwater, sanitaire voorzieningen en de aanwezigheid van geschoold personee/44.

Als de Speciale Rapporteur dit soort interpretaties zou verwerken in haar rapport zou zij bevestigen dat geweld tegen vrouwen hun recht op gezondheid schendt en duidelijk maken welke consequenties die bevinding heeft. Het zou mooi zijn als zij het tot haar taak zou rekenen de manier waarop het Comité inzake Economische, Sociale en Culturele Rechten dit recht heeft geinterpreteerd, nader uit te werken door in te gaan op het perspectief van vrouwen, door bijvoorbeeld te wijzen op de noodzaak dat hulpverleners gespecialiseerd zijn in het herkennen van slachtoffers van geweld en adequaat zijn opgeleid om met de problematiek om te gaan.

\section{Verplichtingen voor de overheid geweld tegen vrouwen te voorkomen en te bestrijjden}

De zojuist genoemde woorbeelden lieten zien hoe we kunnen aansluiten bij terminologie die in discussies over de rechten van de mens gebruikelijk is en dat het zinvol is verder te onderzoeken hoe we de inhoudelijke uitleg door deskundigen op het gebied van de rechten van de mens kunnen gebruiken, Ik ga nu naar het volgende punt van mijn betoog over de mensenrechtenbenadering. I $\mathrm{k}$ al de verdragen over de rechten van de mens als uitgangspunt nemen om te laten zien hoe we deze kunnen gebruiken in het invullen van het recht gevrijward te zijn van geweld. Zoals ik eerder betoogde, is het nodig am bij het toetsen van 
de internationale alansprakelijkheid van de staat onderscheid te maken tussen de verantwoordelijkheid van de staat voor zijn eigen handelen, en verantwoordelijkheid woor de handelingen van privé-personen. $k$ begin met verplichtingen die handelingen van de staat zelf betreffen. Allereerst ga ik in op het VN Verdrag tegen Marteling; omdat dat vergaande en strikt omschreven verplichtingen oplegt aan verdragsstaten om marteling en andere onmenselijke behandeling te voorkomen en te bestrijden. Deze verplichtingen gelden in de eerste plaats woor handelingen van overheidsfunctionarissen. Zo zijn staten verplicht marteling strafbaar te stellen en wetgeving effectief te handhawen en dienen zij klachtprocedures in te stellen. Het Comité tegen Marteling, dat toezicht houidt op de nalewing vain dit verdrag, heeft bepaald geen goede reputatie als het gaat om het bewustzijn dat het nodig kan zijn specifieke aandacht aan de positie van vrouwen te besteden. Het Comité heeft mij onlangs verrast met een aantal interessante uitspraken, die ik graag met $u$ wil delen. Vervolgens ga ik in op een andere werplichting die verdragen aan staten opleggen, te weten de verplichting discriminerende wetgeving te wijzigen of af te schaffen.

Het recht gevrijwaard te zijn van marteling en andere onmenselijke behandeling is een van de meest fundamentele rechten van de mens en het is een van de sterkst beschermde rechten in het internationale recht. Het is vastgelegd in alle algemene mensenrechtenverdragen, daarnaast hebben zowel de Verenigde Naties als de Raad van Europa en de Organisatie van Amerikaanse Staten speciale verdragen in het leven geroepen teneinde dit fenomeen uit te bannen.

De meeste verplichtingen in het $V N$ Verdrag tegen Marteling zijn onmiddellijke verplichtingen. Er is geen toets of staten "met gepaste inzet" hebben gehandeld; niet-naleving van verplichtingen leidt tot aansprakelijkheid. In halr rapport maakt de Speciale Rapporteur in het geheel geen gebruik van dit Verdrag. Dat is jammer. Ik ken witeraard de verwijten dat de reikwijdte van het Verdrag beperkt zou zijn omdat het moeilijk of zelfs onmogelijk zou zijn huiselijk geweld eronder te brengen, en dat het Comité tegen Marteling, dat toezicht houdt op de naleving van dit Verdrag niet gevoelig is voor de ervaringen van vrouwen. Niettemin ben ik van mening dat dit Verdrag een onderschat instrument is in de strijd tegen geweld tegen vrouwen.

De definitie in artikel 1 bepaalt dat sprake is van marteling als het gaatt om het opzettelijk toebrengen van hevige pijn of hevig leed met een 
bepaald oogmerk (zoals het werkrijgen van een bekentenis, maar ook om te intimideren, te dwingen, of gebaseerd op discriminatie). "door of op aanstichten van dan wel met de instemming of gedogen van een ovefheidsfunctionaris of andere persoon die in een officiele hoedanigheid handelt". De tekst van dit verdrag reflecteert enerzijds dat het beoogt bescherming te bieden tegen onderdrukkende regimes, anderzijds het gebrek aan bewustzijn van het probleem van geweld tegen vrouwen ${ }^{45}$. veel schendingen van de lichamelijke en geestelijke integriteit van vrouwen vallen op het eerste gezicht niet binnen de reikwijdte van dit Verdrag, niet omdat het leed niet ernstig genoeg zou zijn of omdat het niet met een bepaald doel wordt toegebracht, maar omdat directe betrokkenheid van de overheid afwezig is. Met Byrnes ben ik voorstander van een ruime interpretatie van het begrip "gedogen", in die zin dat er indirecte aansprakelijkheid voor een staat voor handelingen van privépersonen bestaat, als hij onwoldoende maatregelen treft om ernstige vormen van geweld tegen vrouwen te voorkomen en te bestrijder ${ }^{46}$. Het Comité tegen Marteling lijkt te neigen naar deze interpretatie, zoals ik straks zal laten zien in een aantal voorbeelden.

Geweld door de overheil betreft onder meer geweld door soldaten in oorlogstijd en geweld tegen personen die zich binnen het gezag van de overheid bevinden, bijvoorbeeld als arrestant of gevangene 4 . Veel geweld in detentie is sekseneutraal; zowel vrouwen als mannen worden het slachtoffer van mishandeling. Niettemin worden wrouwen ook op een andere manier slachtoffer van mishandeling dan mannen, meestal in de vorm seksueel geweid, zoals verkrachting, dreiging met verkrachting 4.8 , gedwongen $z$ wangerschap, mishandeling vam $z$ wangere vrouwen met het doel een miskraam te veroorzaken en verplichte gynaecologische onderzoeken ${ }^{49}$. Dergelijke vormen van geweld zijm onaanvaardbaar en het staat buiten kijf dat deze binnen de reikwijdte van het Verdrag vallen.

Het tweede verwijt dat gericht is tegen het Comité tegen Marteling: is dat het de specifieke ervaringen van vrouwen niet in acht neemt. Het besteedt in zijn landencommentaren nauwelijks aandacht aan de zojuist genoemde seksespecifieke schendingen van het Verdrag. In recente landencommentaren besteedt het Comite tegen Marteling well expliciete aandacht aan de positie van vrouwen. Zo spreekt het zijn zorgen uit over marteling op grote schaal, waaronder werkrachting door Togolese militairen, die onbestraft blijven ${ }^{50}$. Ook spreekt het zijin grote 
zorgen uit over het op grote schaal voorkomen van seksueel geweld in detentiecentra, en stelt dat vrouwen uitsluitend door vrouwelijke gevangenisbewaarders zouden moeten worden bewaakt. Het leidt dit als verplichting af uit artikel 11 , dat de verplichting bevat de regelingen voor bewaring en bewaking stelselmatig te onderzoeken en te herzien waar nodig teneinde marteling te voorkomen $n^{51}$. Ook in het geval van Georgië maakte het Comitê $z$ ch zorgen over de situatie van wrouwelijke gevangenen en vond dat goede klachtprocedures moesten worden ingesteld 52 . Dat is een stap vooruit: voor de duidelijkheid zou het nog beter zijn geweest als het Comite expliciet had gezegd dat dit soort procedures en de desbetreffende klachtencommissies deskundig zijn op het gebled van seksespecifieke schendingen.

Op basis van deze recente landencommentaren ben ik dan ook voorzichtig optimistisch, het lijkt erop dat ook in het Comité tegen Marteling is doorgedrongen dat het nodig kan zijn specifieke aandacht aan marteling van vrouwen te besteden. Het Comité kan zijn rol ten aanzien van seksespecifieke schendingen nog verder uitbreiden. Het zou in zijn onderzoek van landenrapporten systematisch informatie kunnen vragen over de samenstelling van de gevangenispopulatie en het personeel dat gevangenen bewaakt, of seksespecifieke schendingen als seksueel misbruik expliciet zijn verboden, op welke wijze klachten over dergelijke schendingen worden onderzocht, enzovoort. Als het Comité dit soort informatie zou gaan vragen via zijn richtlijnen voor rapportage, en in de lijst van bespreekpunten zou opnemen, zou het duidelijk maken dat het verdrag voor vrouwen die onder het gezag van de overheid vallen, even relevant is als voor mannen. Ook kan het Comité gebruik maken van de procedure onder artikel 20 , die het Comité de mogelijkheid biedt onderzoek in te stellen naar systematische martelpraktijken. Het zou een goed signaal zijn als het daarbij structureel speciale aandacht aan de positie van vrouwen zou besteden.

Vrouwenorganisaties kunnen een belangrijke rol spelen in het ontwikkelen wan de deskundigheid wan het Comité tegen Marteling. Zij gebruiken dit verdrag en de toezichtprocedures nauwelijks. Geweld door de staat is wellicht niet het grootste probleem van vrouwen, het komt wel degelijk op grote schaal voor en verdient de aandacht. Er zijn vrijwel geen individuele klachten van vrouwen die betrekking hebben op seksespecifieke schendingen ${ }^{53}$, en ook schaduwrapporten zijn schaars. tk hoop dan ook dat dit in de toekomst verandert en dat niet-gouverne. 
mentele organisaties die zich met geweld tegen vroumen bezighouden in deze ontwikkelingen een goede aanleiding zien om schaduwrapporten aan het Comité tegen Marteling voor te leggen met informatie over tekortkomingen in wetgewing, beleid en praktijk inzake geweld tegen vrouwen, zodat dit Comité kan voortgaan op de ingeslagen we ${ }^{54}$.

De verplichting niet te discrimineren op basis van geslacht is ook een verplichting die geen uitstel duldt. Er mag geen wetgeving, beleld of bestuurlijke maatregelen worden aangenomen of in stand gehouden die in strijd is met het beginsel van non-discriminatie en gelijke behandeling; de overheid moet onderzoeken of dergelijke wetgeving bestaat en deze intrekken of a anpassen ${ }^{55}$. Het laten bestaan van discriminerende wetgeving is een schending van verdragsverplichtingen en leidt tot internationale aansprakelijkheid. Hieronder geef ik een aantal woorbeelden van discriminerende wetgeving die bijdraagt aan het instandhouden van geweld tegen vrouwen.

In veel landen is verkrachting binnen het huwelijk niet strafbaar, waardoor het recht van vrouwen op lichamelijke integriteit onvoldoende is gewaarborgd. Oolk komt het voor dat de strafwet voorziet in strafvermindering voor een verkrachter die met zijn slachtoffer trouwt, ondat hij daarmee haar eer zou redden. Met name in een aantal Islamitische landen is het bewijzen van verkrachting zo goed als onmogelijk, omdat buitenproportionele eisen aan de bewijslast worden gesteld, zoals de noodzaak de getuigenis van vier mannen te overleggen. Indien dergelijke bewijsvoering niet slaagt, loopt de desbetreffende vrouw groot risico op een veroordeling voor overspel. Wetgeving die het mishandelen of doden van vrouwen, omdat zij de eer van de familie zouden hebben beschadigd, niet strafbaar stelt of slechts zeer mild bestrafti, is eveneens in strijd met deze verplichting. Verdragen op het gebied van de rechten van de mens leggen deze verplichting op aan verdragsstaten; niet-naleving van deze verplichtingen kan niet worden gerechtvaardigd en leidt tot aanspra* kelijkheid. Ook hier is een toets of de staat "met gepaste inzet" heeft gehandeld niet aan de orde.

Onder de verplichting direct en indirect discriminerende wetgeving en beleid af te schaffen of te wijzigen valt de verplichting te letten op de effecten van sekseneutraal beleid. Veel vormen van geweld vinden hun oorsprong in gewoontes en tradities. Stereotiepe opvattingen over vrouwen en mannen hebben de doorbraak naar de erkenning dat geweld 
tegen vrouwen een schending is van de rechten van de mens lang belemmerd. Praktijken als genitale verminking van meisjes en vrouwen en eerwraak zijn diep geworteld in een cultuur en daardoor moeilijk aan te pakken. Als er geen overtuiging is binnen de groep (en dat behoeven dan beslist niet alleen mannen te zijn), is verandering uiterst moeizaam te bewerkstelligen. Dit betekent echter niet dat tradities of cultuur een rechtvaardiging kurnen vormen yoor het gedogen van geweld 56 . Het recht gewrijwaard te zijn van geweld gaat boven het behoud van cultuur, zoals blijkt uit de VN Verklaring inzake Geweld tegen Vrouwen, die bepaalt dat staten gewoontes, tradities of religieuze overwegingen niet mogen inroepen om geweld tegen vrouwen te rechtvaardigen.

Dit gaat niet alleen op voor de in de Nederlandse samenleving voorheen onbekende vormen van geweld tegen wrouwem. Ook andere vormen van vrouwenmishandeling komen voort uit ongelijke machtsverhoudingen. Om de oorzaak aan te pakken, is een beleid noodzakelijk dat is gericht op de uitbanning van vooroordelen, gewoontes en praktijken die de notie van superioriteit of inferioriteit van een van beide sekses, en stereotype opvattingen in stand houden. Deze verplichting is met zoveel woorden opgenomen in het VN Vrouwenverdrag, en het Comité inzake Economische, Sociale en Culturele Rechten beschouwt het als onderdeel van artikel 3 van het Internationale Verdrag inzake Economische, Sociale en Culturele Rechten ${ }^{57}$. Maatregelen als het alannemen van wetgeving en het beschikbaar stellen van opvanghuizen zijn verre van voldoende.

De VN Speciale Rapporteurs inzake Geweld tegen Vrouwen, eerst Radhika Coomaraswamy en nu Yakin Ertürk, hebben op basis van voorbeelden van goed beleid in verschillende landen en op basis van onderzoek door wetenschapsbeoefenaars en niet-gouvernementele organisaties vooruitgang geboekt in het opstellen van een lijst maatregelen die stiaten zouden moeten treffen.

Bij het voorbereiden en implementeren van beleid dient de overheid als uitgangspunt te nemen dat geweld tegen vrouwen discriminatie is. Het is niet nodig an te tonen dat de staat direct betrokken is of dat de staat geweld tegen mannen anders behandelt dan geweld tegen vrouwen. Geweld tegen vrouwen kan als discriminatoir worden opgevat, het is een uiting van ongellijkheid en het houdt die in stand 58 . Het is dus niet nodig te onderzoeken of iemand anders beter wordt behandeld, maar of de behandeling op zichzelf door de beugel kan. Een vernederende behandeling die de menselijke waardigheid aantast, is altijd verwerpelijks9. 
Wil beleid gericht op voorkomen en uitbannen van discriminatie effectief kunnen zijn, dan moet het zich richten op de emancipatie van vrouwen en op hun "empowerment". Het zou dus moeten zijn ingebed in het emancipatiebeleid. Het is nodig te onderzoeken of sekseneutrale wetgeving en beleid een negatieve invloed kan hebben op de positie van vrouwen 60 . Om dit te verduidelijken gebruilk ik een Nederlands voorbeeld.

Het door de regering gevoerde diversiteitsbeleid heeft ertoe geleid dat de diverse nota's over huiselijk geweld bewust sekseneutraal zijn. Het neutrale karakter blijkt al uit het taalgebruik. Het gaat over huiselijk geweld, niet over vrouwenmishandeling en kindermishandeling, de pleger wordt (ex-) partner of ouder genoemd. Uiteraard komt geweld door vrouwen ook woor, en kunnen mannen ook slachtoffer zijn van geweld. Dit is misschien een nog wel groter taboe dan vrouwenmishandeling, en het is zinvol dat daar ook beleid voor gemaakt wordt, maar het aantal gevallen waarin vrouwen door hun mannelijke partner of ex-partner worden mishandeld, overstijgt de omvang van dat probleem vele malen, hetgeen niet genegeerd mag worden.

Een sekseneutraal beleid doet wolstrekt geen recht aan de oorzaken en omvang van geweld tegen vrouwen. De nota's erkennen dat "bij vrouwelijke slachtoffers het geweld echter een hogere intensiteit [blijkt] te hebben dan bij mannen" en dat "het geweld tegen vrouwen vaker seksueel van aard [is]" en dat "de dader in $80 \%$ van de gevallen een man blijkt te zijn"61. Het blijft echter bij deze constatering. Dat de overheid geweld tegen vrouwen als veiligheidsprobleem beschouwt, is uiteraard winst. Het wordt niet langer gezien als een probleem van individuele vrouwen, maar als een maatschappelijk probleem.

Seksespecifiek beleid zien we alleen waar het bepaallde vormen van geweld betreft, die uitsluitend onder allochtonen voorkomen, zoals genitale verminking en eerwraak ${ }^{62}$. De desbetreffende nota's wekken daarmee onterecht de indruk dat vrouwenmishandeling alleen onder allochtonen voorkomt. Het beleid dat voor deze onderwerpen wordt gevoerd, is een uitstekend voorbeeld voor hoe beleid gemaakt zou moeten worden voor andere wormen van huiselijk geweld. Sekseneutraal beleid miskent de belangrijkste oorzaak vam het voorkomen van geweld tegen vrouwen. 
Voorlichting en campagnes zijn belangrijk bij de bevordering van de bewustwording van wouwen en mannen dat geweld onacceptabel is. Lange tijd meende het kabinet geen landelike publiekscampagnes te kumen woeren omdat deze een hulpuraag zouden oproepen waaraan niet kon worden woldaan. Om die reden zijn alleen diverse lokale en regionale campagnes gevoerd waar het hulpaanbod voldoende was ${ }^{63}$ Onlangs is besloten dat het nu wel verantwoord is een landelijke campagne te voeren; deze zal komend voorjaar van start gaan.

Ik wil hier niet de indruk wekken dat het allemaal kommer en kwel is met het Nederlandse beleid op huiselijk geweld. De inspanningen am een landelijk dekkend netwerk van Steunpunten Huiselijk Geweld op te zetteri zlin succesvol; er is al een aantal jaren geleden een wet aangenomen die belaging strafbaar stelt, en er is momenteel een wetsvoorstel aanhangig dat de burgemeester de mogelijkheid geeft de pleger van huiselijk geweld tijdelijk uit huis te plaatsen, om op die manier voor een time-out te zorgen. Tot voor kort zou dit ondenkbaar zijn geweest. Het is immers een maatregel die ingrijpt in de privacy van de betrokkenen ten gunste van het voorkomen van escalatie van een situatie van huiselijk geweld. Niettemin is het een grote tekortkoming dat het Nederlandse beleid inzake huiselijk geweld sekseneutraal is en daarmee geen specifieke aandacht geeft aan de situatie van vrouwen. Het Ministerie van Justitie, dat het beleid inzake huiselijk geweld coördineert, heeft onlangs zijn beleid juist op dit punt laten evalueren ${ }^{64}$, $\mathrm{k}$ hoop van harte dat de bevindingen van dit onderzoek serieus worden genomen en dat de aanbevelingen zullen worden geimplementeerd.

\section{De verplichting bescherming te bieden tegen geweld door privé- personen}

Als we onderzoeken of de overheid woldoende maatregelen heeft getroffen om individuen te beschermen tegen geweld door andere individuen, is het zinvol te na te gaan wat regionale mensenrechtenhoven en VN comités daarover hebben gezegd.

Het standaardarrest van het Europese Hof voor de Rechten van de Mens waarin het toetste of een staat genoeg had gedaan om de ene burger tegen de andere te beschermen is het Osman arrest. Deze zaak betrof een moord die was gepleegd na diverse bedreigingen door de latere moordenaar. Volgens het Hof heeft een staiat de verplichting het 
recht op leven te beschermen, maar deze verplichting mag niet 20 worden geinterpreteerd dat het onmogelijke van de staat wordt gevralagd. of dat het een disproportionele last op de staat legt. Het criterium is of de autoriteiten alles hebben gedaan dat redelijkerwijs kon worden verwacht om een reele en onmiddellijke bedreiging van het leven, waarvan zij kennis hadden, of hadden moeten hebber, af te wenden.

In het arrest M.C. tegen Bulgarije onderzocht het Hof of het Bulgaarse recht voldoende bescherming bood tegen verkrachting. Het concludeerde dat dit niet het geval was, omdat voor het vervullen wan de delict5omschrijving van verkrachting vereist was dat er, naast de ongewenste seksuele handeling, sprake was van geweld of dreiging met geweld. Het Hof onderzocht de strafbepalingen in andere Lid-Staten van de Raad van Europa en de praktijk van het Joegoslavië Tribunaal en concludeerde dat er een universele trend was om afwezigheid van toestemming als essentieel element van verkachting en seksueel misbruik te beschouwen, en niet geweld of bewijs van verzet tegen het misbruik 66 . Door te oordelen dat het EVRM de strafbaarstelling en effectieve vervolging vereist wan elke seksuele handeling waarvoor geen toestemming is verleend, ook als het slachtoffer zich niet fysiek heeft verzet, vulde het Hof de verplichtingen onder het EVRM dus heel concreet in, en perkte het de beoordelingsvrijheid van de staat aanzienlijk in. Deze uitspraak betreft geweld in de openbare ruimte, maar is ook relevant voor geweid in de privé-sfeer. Mijns inziens kan hieruit worden afgeleid dat staten ook een verplichting hebben verkrachting en andere seksuele delicten - in de zin van seks zonder toestemming - binnen het huwelijk of een andere intieme relatie strafbaar te stellen en te handhaven.

Andere relevante uitspraken van het Europese Hof betreffen gevallen van ernstige kindlermishandeling. Hoewel dit een andere problematiek betreft dan geweld tegen vrouwen, denk ik toch dat deze uitspraken aanknopingspunten bieden voor het concretiseren van overheidsverplichtingen op het gebied van geweld tegen wrouwen in de prive-sfeer. Het is inmiddels vaste jurisprudentie van het Hof dat het EVRM de verplichting inhoudt te verzekeren dat individuen niet het slachtoffer worden van mishandeling ${ }^{67}$. Maatregelen moeten effectieve bescherming bieden, met name aan kinderen en andere kwetsbare personen. In de zaak $Z$ tegen het Verenigd Koninkrijk leed het geen twijfel dat het geweld en de verwarlozing waaronder de kinderen jarenlang hadden geleden onmenselijke en vernederend behandeling waren in de zin van 
artikel 3. De plaatselijke autoriteiten waren op de hoogte, en hadden verschillende maatregelen tot hun beschikking om in te grijpen, waaronder uthuisplatsing van de kinderen. Het Hof erkende dat de beslissing om zulke maatregelen te treffen uitermate gevoelig lag, en dat het recht op privacy en gezinsleven gerespecteerd diende te worden. Het stelide echter dat het in deze zaak geen twilfel leed dat het systeem had gefaald in de bescherming van de betrokken kinderen tegen ernstige en langdurige mishandeling en verwaarlozing 68 . Het Hof ging overigens niet nader in op de mantier waarop het de afweging maakte tussen het respect voor privacy en het voorkomen en stoppen van mishandeling. In een andere zaak voegde het Hof toe dat het niet vereist was aan te tonen dat het ingrijpen door de autoriteiten de (escalatie van) mishandeling had kunnen woorkomen. Het nalaten redelijkerwijs beschikbare maatregelen te treffen die een reëel vooruitzicht boden op een andere uitkomst. of op minder leed was volgens het Hof voldoende om tot verantwoordelijkheid van de staat te concluderen. In deze zaak vond het EHRM dat er een patroon was van afwezigheid wan onderzoek, communicatie en samenwerking door de relevante autoriteiten, dat een wezenlijke invloed had op het verloop van de gebeurtenissen. Indien zij adequaat en effectief zouden zijn omgegalan met hun verantwoordelijkheden hadden $z i j$, aldus het Hof "het risico kunnen verkleinen of het leed kunnen verminderen 69 .

Een andere vorm wan geweld, namelijk uitbuiting vam huishoudelijk personeel, was aan de orde in de zaak Siliadin tegen Frankrijk ${ }^{70}$. Artikel 4 EVRM bevat het recht niet te worden onderworpen aan slavernij, dwang arbeid en dienstbaarheid. Mw. Siliadin, een minderjarig Togolees meisje, had jarenlang onafgebroken, tegen haar wil en onbetaal d gewerkt in het huishouden van een echtpaar. Haar identiteitspapieren waren afgepakt. Omdat zij minderjarig was en illegaal in Frankrijk verbleef, bang was voor arrestatie en uitzetting, concludeerde het Hof dat er sprake was van werken onder awang. Het Hof wond dat er geen sprake was van slavernij, omdat er geen sprake was van "juridisch eigendom" waardoor zij tot object was gereduceerd. Het Hof vond wel dat er sprake was van dienstbaarheid - zij was verplicht onder dwang haar diensten te verlenen. Ze had geen bewegingsurijheid en geen vrije tijd en was totaal afhankelijk van het echtpaar woor wie zij werkte. In het Franse strafrecht was weliswaar uitbuiting wan arbeid en tewerkstelling onder onwaardige omstandigheden strafbaar, maar slavernij en dienstbaarheid waren niet als zodanig strafbaar gesteld. Op grond van de bestaande bepalingen 
was het echtpaar vrijgesproken. Het Hof concludeerde dat de Franse strafbepalingen geen effectieve bescherming boden, in strijd met artikel 4. Het Hof onderschreef de conclusie van de Parlementaire Vergadering, dat vooral vrouwen in slawernijachtige omstandigheden in huishoudelijk werk worden uitgebuit, maar deed hier - helaas - verder niets mee. Het besteedde wel bijzondere aandacht aan het feit dat Siliadin minderjarig was en daardoor extra kwetsbaar?

In Siliadin tegen Frankrijk en M.C. tegen Bulgarije heeft het Europese Hof aangegeven dat specifieke strafbaarstelling voor dienstbaarheid, respectievelijk werkrachting, noodzakelijk is woor een effectieve garantie van de rechten die in het geding waren. In M.C. tegen Bulgarije sprak het Hof zich zelfs heel concreet uit over de inhoud van de strafbepaling. Dit soort uitspraken zijn nuttig voor de nadere concretisering wan verplichtingen van de rechten van de mens die bij geweld tegen vrouwen in het geding zijn. Het Hof baseerde de verplichting tot specifieke strafbaarstelling op de verdragsbepaling. Het zou daarom zinvol zijn als studies en rapporten daarbij expliciet zouden aansluiten. In de zaken over kindermishandeling was niet zozeer de wetgeving het probleem, als wel het falen van instellingen op het gebied van jeugdzorg. Het bijzondere aan deze uitspraken is dat het Hof naar het complete verhaal heeft gekeken, en verantwoordelijkheid van de autoriteiten vaststelde omdat zij escalatie van de kindermishandeling binnen de gezinthen hadden kunnen voorkomen. De toets die het Hof daarbij hanteerde is of het redelijkerwijs mogelijk was geweest in te grijpen om verder leed te voorkomen. Bij het beoordelen van aansprakelijkheid van de overheid in concrete gevallen van vrouwenmishandeling kan deze toets ook worden gebruikt. Jurisprudentie van het Hof over marteling en andere onmenselijke en vernederende behandeling en zijn progressieve interpretaties in verschillende arresten maken het aannemelijk dat het Hof in geval van ernstig huiselijk geweld een schending van artikel 3 EVRM zal vinden 72.

Het VN Comite tegen Marteling heeft inmiddels een arandeel geleverd in het invullen van verplichtingen ten aanzien van geweld tegen vrouwen ook als dat niet direct is toe te schrijven aan handelen door of namens overheidsfunctionarissen. Het landencommentaar over Togo van mei 2006 bevat een aantal opvallende conclusies en aanbevelingen. Het Comité tegen Marteling liet zich zeer positief uit (het gebruikte de term "applauds") over het totstandkomen van wetgewing in Togo die genitale verminking van vrouwen en meisjes verbiedt ${ }^{73}$. Vervalgens 
sprak het zijn zorgen uit over het voortbestaan van deze praktijk en stelde dat Togo alle noodzakelijke maatregelen moest treffen om deze praktijk uit te bannen, waaronder het voeren van campagnes gericht op bewustwording, maar ook door het bestraffen van de plegers. Het bracht deze problematiek onder artikel 16 van het Verdrag tegen Marteling, dat het recht bevat gevijwaard te zijn van wrede, onmenselijke of vernederende behandeling of bestraffing. Ook artikell 16 zlet alleen op handelingen die zijn gepleegd "door of op aanstichten van dan wel met de instemming of gedogen van een overheidsfunctionaris of andere persoon die in een officiéle hoedanigheid handelt", deze aanbeveling aan Togo is dus een belangrijke stap vooruit in het werk van dit Comite. Een ander onderwerp dat het Comité nu tot zijn terrein rekent, is handel in wrouwen en kinderen, ook dit brengt het binnen artikel $16^{75}$. In het landencommentaar over Georgië verwelkomde het Comité wetgeving over huiselijk geweld ${ }^{76}$.

Tot woor kort vielen deze onderwerpen geheel buiten het blikveld wan het Comité, en met deze aanbevelingen lijkt het Comitee en nieuwe weg te zijn ingesilagen. Het classificeert (nog?) niet alle vormen van huiselijk geweld als marteling, zoals door verschillende juristen bepleit 77 , maar heeft nu een aantal ernstige vormen van geweld aangeduid als wrede, onmenselijke of vernederende behandeling. Dit heeft consequenties woor de toepasbaarheid van een aantal verdragsbepalingen; zo is het verbod van refoulement in artikel 3 niet van toepassing op mishandeling in de zin van artikel 16 . Niettemin verwelkom ik deze stap vam het Comité. Het is niet uit te sluiten dat het ernstige vormen van huiselijk geweld als marteling zal kwalificeren, hetgeen tot gevolg heeft dat de vergaande verplichtingen uit het verdrag tegen Marteling van toepassing zijn.

De Inter-Anverikaanse Commissie voor de Rechten van de Mens heeft nog niet veel uitspraken gedaan naar aanleiding van klachten over schending van het inter-Amerikaanse Verdrag inzake de Uitbanning van Geweld tegen Vrouwen. In de zaak Maria da Penha Maia Fernandes tegen Brazlllë liet de Commissie goed de walarde van de concrete bepalingen in dit Verdiag zien. De zaak betrof een vrouw die langdurig slachtoffer was geweest van ernstige mishandeling en poging tot moord door haar echtgenoot. Aanvankelijk was zij te bang om bij hem weg te gaan, maar na een tweede poging tot moord startte $z i j$ een echtscheidingsprocedure, waama de autoriteiten het geweld gingen onderzoken. Haar ex-echtgenoot was in eerste aanleg veroordeeld, maar dat was gevolgd 
door hoger beroep. Al met al duurden de juridische procedures meer dan 15 jaar, en al die tijd was hij op vrije voeten, ondanks de ernst van de aanklachten tegen hem en de grote hoeveelheid bewijs ${ }^{78}$. De InterAmerikaanse Commissie vond schendingen van verschillende verdragsbepalingen, zowel van het inter-Amerikaanse Verdrag voor de Rechten van de Mens als van het specifieke Verdrag inzake de Uitbanning van Geweld tegen Vrouwen.

Voor dit onderdeel is vooral interessant hoe de Commissie de specfieke verplichtingen uit het Verdrag inzake de Uitbanning van Geweld tegen Vrouwen invulde. De Commissie onderzocht niet alleen dit individuele geval, maar constateerde op basis van diverse rapporten die beschikbaar waren, dat het geval niet op zichzelf stond, maar deel uitmaakte van een patroon. Het benadrukte dat het feitelijk gedogen van geweld bijdraagt aan het instandhouden van de psychologische, sociale en historische oorzaken die ten grondslag liggen aan geweld tegen vrouwen. Het gebrek aan effectief optreden tegen plegers van huiselijk geweld hield volgens de Commissie een schending in vân de verplichting geweld tegen vrouwen te voorkomen, omdat dit bijdroeg aan het instandhouden van een klimaat van geweld tegen vrouwen. De staat liet immers geen bereidheid zien om dergelijk geweld effectief te bestrijden. De positieve maatregelen die Brazilië had getroffen werden door de Commissie gewaardeerd; maar het oordeel was uiteindelijk dat het gebrekkige optreden van de rechterlijke macht, de straffeloosheid van de plegers van huiselijk geweld en de onmogelijkheid voor slachtoffers compensatie te krijgen een woorbeeld vormden van onvoldoende bereidheid passende maatregelen te treffen om huiselijk geweld aan te pakken. De Commissie concludeerde ulteindelijk dat Brazilliè zijin verplichtingen uit het Verdrag niet had nageleefil en dat een groot aantal bepalingen was geschonden 79 .

Opvallend is dat zowel het Europese Hof als de Inter-Amerikaninse Commissie tot de conclusie komen dat "het systeem" heeft gefaald; dit biedt perspectieven voor zaken van geweld tegen vrouwen. De InterAmerikaanse Commissie lijkt een flinke stap verder te gaan dan het Europese Hoff, door niet alleen te concluderen dat het systeem in een individueel geval is tekortgeschoten, nee, het systeem deugt helemaal niet. Het goede nieuws is dat Braziliě in augustus 2006 specifieke wetgeving heeft aangenomen ter voorkoming en bestrijding van huiselijk geweld; deze wet staat bekend als de "Maria da Penha wet" 
Al snel nadat het Protocol dat een individueel klachtrecht mogelijk maakte onder het WN Vrouwenverdrag in werking was getreden, kreeg. het Comité inzake de Uitbanning van Discriminatie van Vrouwen een klacht over huiselijk geweld voorgelegd. Een Hongaarse vrouw, MW. T. was jarenlang mishandeld door haar partner, inmiddels haar ex-partner. Zij kon geen toevlucht nemen tot een opvanghuis, omdat er geen plaats. was voor haar en haar kinderen, waarvan er één ernstig gehandicapt. was. Civielrechtelijke procedures leidden niet tot een bevredigend resultaat; het bleek onmogelijk haar ex-partner de toegang tot de woning te antzeggen, het was, aldus de rechtbank, immers ook zijn woning. Strafrechtelijke procedures sleepten jaren voort, en leidden witeindelijk slechts tot een boete, ondanks bewijs van de ernstige mishandeling die hij had gepleegd, die verschillende keren noopten tot opname in het ziekenhuis. Gedurende de periode dat dit speelde, was hij nooit in hechtenis genomen, en waren geen maatregelen ter beschermingvan MW.T.getroffen - het Hongaarse recht kende niet zoiets als een straatverbod ${ }^{81}$. Aan de hand van zijn algemene aanbeveling over geweld tegen vrouwen 82 onderzocht het Comite in hoeverre Hongarije aan zijn verdragsverplichtingen had woldaan. Het constateerde dat de staat tekortgeschoten was in het bieden van adequate en effectieve bescherming aan slachtoffers van huiselijk geweld. Er waren onvoldoende rechtsmiddelen beschikbaar, en huiselijk geweld zaken hadden geen prioriteit woor de rechterlijke macht. Het Comité bekritiseerde vooral de afwezigheid van specifieke wetgeving voor huisellijk geweld en belaging, de onmogelijkheid een straatverbod voor de pleger van geweld op te leggen, en het gebrek aan opvangmogellijkheden voor slachtoffers. Het vond schendingen van verschillende verdragsbepalingen, alsmede van het recht van $M w$. T. op veiligheid van persoon ${ }^{83}$. Het Comité oordeelde verder dat het recht op gelijkheid in het gezin was geschonden, en dat Hongarije onvoldoende had gedaan om stereotiepe opvattingen over vrouwen uit te bannen ${ }^{84}$. Het Comite heeft met deze uitspraak laten zien hoe het in zijn werk aansluit bij de algemene mensenrechtemverdragen, wat kan bevorderen dat andere $\mathrm{VN}$ comites deze uitspraak in hun eigen werk gebruiken.

\section{Slotopmerkingen}

IK heb in mijn rede willen laten zien wat een mensenrechtenbenadering van de problematiek van geweld tegen vrouwen inhoudt. Dat geweld tegen vrouwen een schending van de rechten van de mens is, 
is algemeen aanvaard. Geweld tegen vrouwen kan inbreuk maken op fundamentele rechten zoals het recht op leven, het recht gevrijwaard te zijn van marteling, het recht op gezond heid en het recht op een effectief rechtsmiddel.

Ik ben ervan overtuigd dat een effectieve aanpak van geweld tegen vrouwen dient te zijn gebaseerd op het bestaande mensenrechteninstrumentarium. Toezichthoudende comités zijn begonnen het perspectief van vrouwen in hun werk op te nemen, maar zij zouden daarin nog veel verder kunnen en moeten gaan. Als functionarissen als de $\mathrm{VN}$ Speciale Rapporteur inzake Geweld tegen Vrouwen in hun werk expliciet verwijzen naar bestaande normen, versterkt dat de redenering dat geweld tegen vrouwen een schending is van de rechten van de mens. Dat kan ertoe bijdragen dat er een einde komt aan de bestaande verkokering van de aandachtsgebieden rechten van de mens en rechten van vrouwen; ook al spreken we over mensenrechten van wrouwen, er is nog onvoldoende kruisbestuiving tussen de twee terreinem. Coherente inter pretatie van internationaal beschermde rechten van de mens bevordert de effectiviteit wan de toezichthoudende organen, wat bijdraagt aan een betere bescherming van de rechten van de mens.

Ik heb betoogd dat het volgen van een mensenrechtenbenadering betekent dat op een andere manier zou moeten wordien omgegaan met de verplichting "met gepaste inzet" te handelen. In de eerste plaats meen ik dat we deze term niet moeten gebruiken voor het formuleren van inhoudelijke verplichtingen van staten om geweld tegen vrouwen te voorkomen en te bestrijden. Het volgen van een mensenrechtenbenadering gaat uit van de rechten zoals deze zijn geformuleerd, uit die rechten wloeien de verplichtingen voort. Bestaande instrumenter kunnen als basis dienen voor het nader concretiseren van verplichtingen, met inachtneming van het perspectief van vrouwen. Het is niet nodig en mijns inziens zelfs onjuist, om dat aan te duiden als verplichtingen om "met gepaste inzet" te handelen.

In de tweede plaats meen ik dat deze term niet gebruikt moet worden woor het beoordelen van handelingen van de overheid zelf. Verdragen op het gebied van de rechten van de mens beteugelen in de eerste plaats het gedrag van de overheid en daarmee wan zijn functiona. rissen. Een overtreding van een verdragsverplichting, zoals marteling of onmenselijke behandeling door een overheidsfunctionaris, en het laten 
voortbestaan van discriminerende wetgeving, leidt tot internationale aansprakelijkheid. Het beoordelen of de overheid al dan niet "met gepaste inzet" heeft gehandeld is een toets die niet streng genaeg is. De toets of de overheid "met gepaste inzet" heeft gehandeld dient dus alleen te worden toegepast op handelingen die niet direct aan de overheid zijn toe te schrijuen, zoals geweld door een privé-persoon.

Door ons te baseren op de rechten van de mens kunnen we het totale beleid van de overheid op deugdelijkheid beoordelen. Met andere woorden, we kunnen nagaan of "het systeem" aan het complex van verplichtingen op basis van internationale instrumenten voldoet. Internationale toezichthoudende instanties kunnen cordelen of in een concreet geval geweld had kunnen worden voorkomen, en of de overheid adequat is opgetreden in gevallen waar zich geweld heeft voorgedalan.

Deskundigen op het gebied van discriminatie van wrouwen in het algemeen en geweld tegen vrouwen in het bijzonder, zoals de Speciale Rapporteur inzake Geweld tegen Vrouwen, maar ook niet-gouvernementele organisaties kunnen een grote rol spelen in het bewust maken van toezichthoudende organen van de ervaringen van vrouwen. Daarnaast hoop ik in mijn werk een bijdrage aan deze discussie te leveren, door nader onderzoek te doen naar zowel de inhoudelijke aspecten van de rechten van de mens als de verantwoordelijkheden van de overheid ten aanzien van geweld tegen vrouwen. Voor mij is dat de uitdaging voor de komende twee jaar.

De blinddoek die in het verleden leidde tot blindheid woor de verhalen van vrouwen begint doorzichtig te worden. De blinddoek van Vrouwe Justitia symboliseert de onafhankelijkheid en onpartijdigheid van de rechterlijke macht, wat ook tot de fundamentele rechten van de mens hoort. Het negeren van relevante verschillen leidt echter tot onrechtvaardige uitkomsten. in dergelijke gevallen moet de blinddoek opzij.

\section{Dankwoord}

Dames en heren,

Ik kom aan het einde van mijn aratie. Ik wil in de eerste plaats mijn dank uitspreken aan allen die deze leerstoel en mijn bekleding diaarvan mogelijk hebben gemaakt. Ik dank de Stichting Opzij en de Universiteit 
Maastricht voor het vertrouwen dat zij in mij hebben getoond met deze benoeming. Ik vind het een grote eer na Maake Meijer, Liesbet van Zoonen en Marli Huijer als vierde vrouw de Opzij-leerstoel te bekleden.

Ik dank mijn collega's van het Centrum voor Gender en Diversiteit voor de inspirerende werkomgeving die zij bieden, en zonder anderen tekort te willen doen, wil ik met name Maaike Meijer en Mineke Bosch bedanken voor het meedenken over de irvulling van mijn onderzoek gedurende de periode dat ik deze leerstoel bekleed. Ik waardeer onze inhoudelijke bijeenkomsten over onderzoek, war ik - als enige jurist in het gezelschap - veel van leer. Het is altijd een goed begin wan mijn Maastrichtse dag als ik het secretariaat binnenloop en even met Wilma Lieben koffie drink. Dankzij de vrolijke en efficiente manier waarop zij haar werk doet zijn allerlei praktische zaken rond deze dag soepel geregeld en krijgt u straks bij de uitgang een fraai gedrukt exemplaar van mijn rede.

Ik heb er hier in Maastricht niet één, maar twee groepen nieuwe collega's bij gekregen. Ik voel mij bij het Centrum voor de Rechten van de Mens van de Juridische Faculteit eveneens zeer betrokken. ik bedank mijn collega's van "de overkant" woor de manier waarop zij mij betrekken bij hun activiteiten. De rechten van de mens en de positie van vrouwen in het recht hebben in Maastricht altijd een speciale plats ingenomen. De band tussen de juridische faculteiten van utrecht en Maastricht is sterk, en ik vertrouw er dan ook op dat nadere samenwerking met Fons Coomans, Menno Kamminga, Ingrid Westendorp, Ria Wolleswinkel, en natuurlijk Theo van Boven, een wan mijn promotoren, zijn beslag zal krijgen gedurende de periode van mijn aanstelling.

Mijn collega's van het Studie- en Informatiecentrum Mensenrechten in Utrecht, het is een groot genoegen met jullie te mogen samenwerken. De bezieling waarmee jullie je vak uitoefenen blijt mij inspireren. Een aantal Utrechtse collega"s wil ik in het bijzonder bedanken. Allereerst mijn promotor, Peter Baehr. Ook na je pensionering profiteer ik regelmatig wan je grote kennis van de rechten van de mens en de nauwgezetheid waarmee je mijn conceptteksten leest.

Beste Kees, ik vind het heel specilaal dat ik hier in jouw toga mijn oratie houd. Mijn leeropdracht past prachtig in de mede door jou vormgegeven Maastrichtse traditie, met veel aandacht voor het internationale 
recht, de rechten wan de mens en vrouw en recht. Ik hoop dat wij in de toekomst nauw zullen blijven samenwerken.

Lieve Jenny, j] bent een van mijn grote voorbeelden, als jurist en als mens. Jouw scherpe inzicht in de rechten van de mens en het gelijkheidsbeginsel in theorie en praktijk zijn voor mijn werk zeer waardevol. lik vind het een mooi toeval - als dat het is - dat ik mijn oratie houd op de datum waarop jij precies twee jaar geleden jouw oratie in Utrecht hield. Laten we volgend jaar weer iets leuks gaan doen op 8 december.

Bestuursleden en MT-leden van Amnesty, wat ik uit mijn samenwerking met jullie haal, bevestigt voor mij dat een wetenschapper niet goed kan functioneren zonder betrokkenheid bij maatschappelijke organisaties. Collega redactieleden van het NICM Bulletin, ik vind dit een mooie gelegenheid om te zeggen hoezeer ik onze samenwerking waa rdeer. Hoe wij er altijd weer in siagen met zijn allen een redactioneel te produceren is mil soms een raadsel, maar altijd een groot genoegen.

Dames en heren studenten, op het gebied van de mensenrechten van vrouwen in het algemeen en geweld tegen vrouwen in het bijzonder liggen nog veel scriptieonderwerpen. Ik hoop op een ruime belangstelling van uw kant voor dit onderwerp, en dat ik $u$ aan het denken kan zetten, en u mil.

Mijn lieve ouders, jullie wil ik bedanken voor alles wat ik van huis uit heb meegekregen, en voor de manier waarop jullie me steeds met raad en daad bijstaan. $\mathrm{k}$ hoop dat ik nog lang met jullie samen in de polder kan uitwaaien. Lieve vrienden en vriendinnen, veel van jullie hebben de moeite genomen naar het zuiden af te reizen. leder van jullie is mij zeer dierbaar en ik prijs mij gelukkig dat ik jullie ook op deze bijzondere dag om mil heen heb.

Ik heb gezegd. 


\section{Notes}

1 Ustina Dolgopol \& Snehal Paranjape, Comfort women. Am wy finished ordect Reyont of a mission. Geneva: International Commission of Jurists: 994 : Amnesty international Canada, still waiting after bo years: fustice for surwors of lapan's sexual shovery system. Al Index A5A 22/o12/2005, 28 October 2005.

2 Advies- en Onderzoeksgroep Beke, Binnen zonder koppen. Omwang, aard en wehtergron. den van hwiselijk geweld in 2005 op basis wan landelinke politieciffers. [s.1.]. 2006.

3 Peggy Kuo, Prosecuting crimes of sexual wolence in an intemational tribunal, in: Case

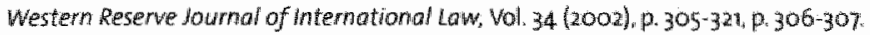

4 Rhonda Copelon, "Intimate terror: understanding donestic violence as torture:" in: Rebecca cook led. Human rights of women. National and intemational perspectives. Philadelphia: University of Pennsylvania Press, 1994, p. 116-152, p. n6-117.

5 AlCONF.157/23, Vienno Declaration and Programme of Action, Part 1, artikel 5 .

6. Hilary Charlesworth, "What are "women's international human rights"?; in: Rebecca cook (ed.). Human rights of women: National and international perspectives. Philadelphia: University of Pennsylwania Press. 1994, p. 58-84, p. 60. Zie ook Jenny E. Goldschmidt Mensenrechten: vouwenechten? Deventer: Kluwer, 1995

7 Deze term ontleen ik aan llerny E. Goldschmidt, We need different stories. Een ander ver. haal in het recht. Werhalen van verschil. Zwolle: Tjeerk Willnk, 1993. Vrouwen waren niet geheel afwezig: tijdens de opsteiling wan de Universele verklaring was Eleanor Roosevelt voorzitter van de Commissie woor de Rechiten wan de Mens.

8. Voon een overzicht van de erkenning van slavernij als schending van de rechteen wan de mens en de strijd wark miet-gouvernementele organisaties zie Kevin Bales, "Non-state actors and the challenge of slavery' in: George Andreopoulos et al. (eds.) Non-state actors in the human rights universe. Bloomfield: Kumiarian, 2006, p. 273-28:8.

9 zre artikel 2 (d) Verdrag inzake de Uitbanning van alle vornen van Rassendiscriminatié: dat verdragsstaten verplicht rassendiscriminatie door personer, groepen of organisaties. te verbieden.

10 Catherine Moore, "Women and domestic wiolence: the public/priwate dichotomy int international law", in: The international Journal of Human Rights, Woll. 27. (2003), No. 4. 19.93-128, p. 104 .

11 Anne Gallagher, 'Ending the marginalization: strategles for incorporating women into the United Nations human rights system; in: Human Rights Quarterly, vol. 19 (1997), p. 283-333. Division for the Advancement of Women, Women 2000 , integrating a gender perspective into UN human rights work. New York: United Nations, 2000.

12 Voor een overzicht van de aanloop naal en het verloop van de conferenties zie Kumaralingam Amirthalingam, "Women's rights, international norms and domestic violence: Asian perspectives, in: Human Rights Quarterly, vol. 27 (2005). p. 683-708, p. 703 . 704. 


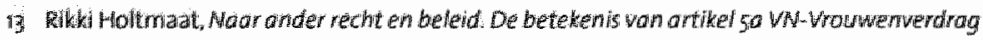
woor het uitbannen van structurele genderdiscriminatie. Den Hagg: Ministerie van Saciale Zaken en Werkgelegenthe d, 2004 , hoofdstuk t3 (p. 85 g).

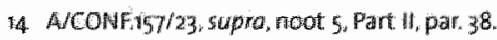

15 A/Conffist/23, supra, noot s. Part II, par. 37.

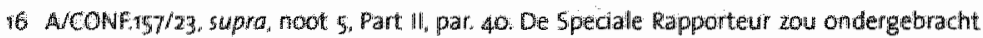
moeten worden bij de Commissie woor de Rechten wan de Mens, niet bil de Commissie inzake de Positie van de Vrouw. Dit is ool gebeurd, zie Commissie voor de Rechten want de Mens kesolutie 1994/44, Question of integrating the rights of women into the human rights mechanisms of the Unithe Nations and the elimination of violence against women.

17 Menserirechtencomite "Ceneral Comment N0. 28, Artiche 3. The equality of rights belween

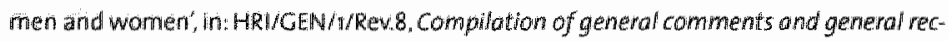
ormmendations adopted by humam rights treoty bodkes, p. 222-223. par. 24: Comite inzake Economilsche, Sociale en Cutturete Rechiter, "Ceneral Comment No. 16. The equal right of men and women to enjoyment of all economic, social and cultural rights'. in: HRI GEN/U/Rev.8, Complation of general comments and generd recommendations adopted by human rights treaty bodies, p. 127-128, par. 27: Comite inzake de Uitbanning van Rassend iscriminatie. Ceneral Recommendation No XXV on gender-related dimensions of racial discrimination. In HRI/CEN/1Rev.8, Compilation of generol comments and general recommendations adopted by human rights treaty bodies, 0.258 .

18 Security Council Resolution 1325 (2000), S/RES/13,25, 31 oktober 2000 , par. 10- 81.

19 In 200 heeft de Algemene Vergadering de Secretaris-Generaal opdracht gegewen tot een orvangrijke adlitergrond studie, zie A/61/12z/Add.1, in-depth study on all forms of violence against women. Report of the Secretary General.

20. Deze woorbeelden zijn door het Comité inzake de Uitbanning van Discriminatie van Vrouwen in zijn landencommentaren als discriminatoir bestempeld. Het comitê beveelt staten structureel aan de minimumleeftija woor huwelijk 18 jaar te maken, in owereen. stemming met het Verdrag inzake de Rechten wan het Kind. Zie oak UNICEF, Early morriage, a harmful traditional practice. A statistical exploration. New Vork: UNWICEF, 2005 .

21 incke Boerefijn, 'Domestic violence againsit women in international law', In: Ingrid Westendorp \& Ria Wolleswinkel (eds). Wialence in the domestic sphere, Antwerpen Oxford: Intersentia, 2005, p. $35-5 \%$

22 Op het moment van schrijuen: was de officiale vershe van de resolutie nog niet beschikbaar.

23 Marjoletr wan den Brink, "Het recht op lichameligke integriteit en het Vrowwenwerdrag" in: NCM-Bulletin, Jrg. 18 (1993), p. 660.573. Vergelijk artikel s (b) van het verdag inzake de Uitbanning van alle vormen van Rassendistriminatie (aangenomen in 1965). op grond warvan verdragstaten werplicht zijn het recht van een ieder, zonder onderscheid nat pas, huidskleur of nationale of etnische afstamming, op gelijkheid voor de wet te verzekeren, in het bigzonder wat het genot van de nawolgende rechten betreft: (...) "het recht op 
persoonlijke veiligheid en bescherming door de stat tegen geweld of lichamelijk letsid, hetzij toegebracht door overheldsdienaren, thetzij door enige andere persown, groep of instelling: Comité inrake de Uitbanning van Discriminatie wan Vrouwem, General Recommendation No. 19. 'Vilence against womer', in: HRIGEN/R/Rew, Complation of geveral comments and general recommendations adopted by humam rights treaty bodies, p. yo: -30 .

25 Algemene Vergadering van de Verenigde Naties, Declarotion on the rimination of Vialence against Women. A/RES/48/104, 20 december 1993.

26. inter-American Convention on the Prevention. Punishment and Eradication of Violence against Women. "Convertion of Belem do Para", 1994 .

27 Protocol to the African Charter on Human and Peoples" kights on the Rights of Women in Africa, 2000 , zie met name artikel 4 .

28 Het Mensenrechtencomité lijkt dit recht ook te erkennen, zie Mensenrechtencomite: supra 17. par. 11.

29 Nederlandse wertaling afkomstig uit Inter-departementale werkgroep ter voonkoming en bestrijding wan geweld tegen wrouwen. Aanzet voor een interdepartementaol plon van aorpok ter woorkoming en bestrijding var geweld tegen wrouwen. Den Haag, ws jaruari 1998. p. 4. De originele Engellse definitle is te vinden in A/CONF,177/20, Report of the Fourth World Conference on Women, Annex ll, Platform for Action, par. 13.

30 Dat verkrachting marteling is, lijkt inmiddels onomstreden. in Cyprus t. Turkje (10 juli 1976) bestempelde de Europese Commissie voor de Rechten wan de Ahens verkrachting nog als onmenselijke behandeling in de zin wan artikel 3 wan het Europese verdrag voor de Rechten van de Mens. Inmiddels zijn er diverse internationale en nationale rachterlijke en quasi-rechterlijke uitspraken dat dergelijke handelingen als marteling dienen te worden geclassificeerd, Voor een overzicht zie Bymes, The Convention Against Torture? in: Kelly D. Askin \& Dorean M. Koenig (eds.). Women and intermational human rights law. Vol. 2. Ardsley/New York: Transnational publishers, 2000, p. 183-208, p. 196-999. Het EHRM heef in Aydir to Turkije, 25 september 1997. Appl, No $23178 / 94$, Reports of Judgments and Decisions, 1996 -V/H; No. 50, verkrachting in de gevangenis gekwalificered als marteling. De Inter-Amerikanse Commissie voor de Rechten van de Mens deed dat in Mejita Egocheaga and Martin de Meja t. Peru, Case no. Report No. 5/96, Case 10.970, 1 matrt 1996, in eun geval van herhaaldelijke werkachting door veilighed smensen wan de stat.

31 Dat dit algerneen geaccepteerd is, blijkt on der meer wit A/CONF, 177/20, supro noot 29, par. 118 , en A/6412z/Add, supro, 19 par 27 en $69-77$ met verwijzhgen maar diwerse weten. schappelijke studies.

32 Zie uitgebreider over verplichtingers Magdalena Sepilveda The noture of the obllgations under the International Covenant on Economic, Social and cultural Rights, Antwerpen: Intersentia, 2003. Over verschillende soorten verplichtirigen spacifiek in het WN Vrowwenverdrag, zie Andrew Byrnes \& lane Connors, 'Entorcing the human rights of women: a complaints procedure to the Women's Convention' In: Brooklyn Jounal of 


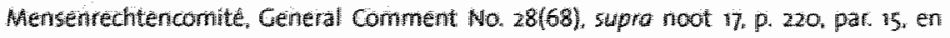
Europees Comte Wnane de Voorkoming wan Martelling The CPT standards, "Substantive"

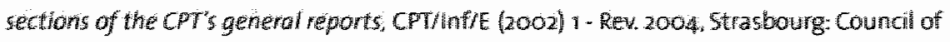
Euroger, 2002, p. 70

52 Combet tegrn Martelng, "Condusions and recommendatons of the Committe against Torture: Ceoratas: in: CAT/C/GEO/CO/y, par. 19.

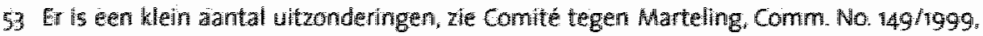

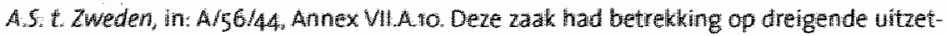
ting wan een vrouw nat lran, waar zil gedwongen was te trowwen met een ayatollah, nadat haar owerleden echtgenoot tot martellar was werklard. Zi was bij afwezigheid ter dood weroordeed was door steniging wegens overspel.

54 Artrew Byrres geeften prachtig owerzich wan die werschillende rnogelijheden die verschilende internationale mensenrechtenorganem bieden in Using international human rights law and procedures to adwance women's human rights, in: D. Askin \& Dorean M. kenig (eds.), Womerl and internotionol humon rights law, Vol. 2. Ardsley/New York: Trans national publishers, 2000, p. 79-118. Chirwa bepleit georukik van andere toezichtprocedures dan alleen de indwiduele Wachtprocedure, zle Danwood Mzikenge Chirwa, "The doctrme of state responsibilty as a potential means of holding private actors accountable:

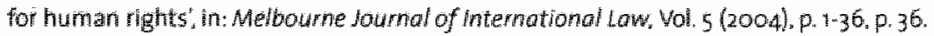

55 Compre inzake Economische, Sociale en Culturele Rechten, supra noot ry, par. 18.

56 Zie verder Goldschmidt, Mensenrechten: wouwentechten?, supra noot 6, p. 13-14. waar zij Stelt dat "het honoreren wan indivicluele mensenrechtemclaims kan niet worden afgeschil. derd als bedreigend voor het voortbestan van de groep, hooguit als bedreiging woor de madsthebters in die groep."

57 WW Wrowenverdrag, antikel $5($ (a), CEDAW, Ceneral Recommendation No. 19, supro noot 24, par, 11, 22m; Comite inzake Ecomomische, Sociale an Culturele Rechten, supra noot ry par. 19. Zle uitgebreider over artikel 5, Vrouwenverdrag Rikki Hoitmaat, supro noot 13.

58 Rhond Copelon, "International human rights dimensions of intimate violance: another strand in the dialectic of feminist lawmaking: in: Jound of Gender, social polfy \& the LoW, Vol. in (2003), p. 865-876. P. 869 .

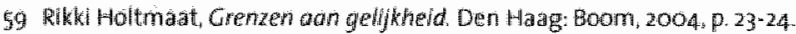

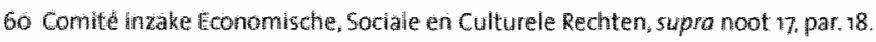

G1 Prive geweld - publieke zaok. Tweede Kamer 20012002,28945 nr. 2, p. 4, en recent in het

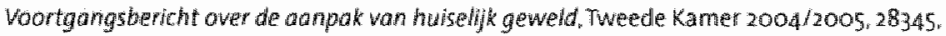
m. 33. wat kinderen, allochtomen en ouderen benomt tot specheke andactsgroepen.

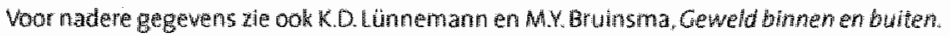
Aard omvang en doders van huiseline en publiek geweld in Nederland. Den Hag: WODC. $200 g_{4}$

6. Fergerelateerd geweld is angewezen als en "groot project." Tweede kamer $2005-2006$, 30388 n. 1 . Eergerelaterd geweld. Brief van het presidinn. Tweede Kamer, $2006 / 2007$. 
30388, nir. 8 , bevat het meest recente voortgangsbericht.

63. Privé geweld-publieke zaak, supra noot 67. par.4.3. p. 34 .

64 Het anderzoek is uitgeverd door kenee Römkens in opdrach van de visitatiecominissie Emancipatie. Op het moment van het afronden van deze tekst was de withomst van het onderzoek nog niet openbaar.

65 EHRM, Osman t. Verenigd Koninkrik. 28 oktober 1998. Appl. No. 23452/94. Reports of Judgments and Decisions 1998-VIH, No.95, par. 176. In dezza zak wond het Hof geen scher. ding van artikel 2. Hierbij speelden de mensenrechten van de bedreiger een belangy rol. Het Hof was van mening dat het de autoriteiten niet kwalijk kon nemen dat zij waarde hechtten aan de onschuldpresumptie, en dat zij van oordeel waren dat de woor matrege. len als huiszoeking en arrestatie verisite verdenking van de bedreiger niet aanwezig was. Het was volgens het Hof niet aarnemelijk gemaakt dat het gebruik van die bewoegdheden tot resulta at zouden hebben geleid (par. 121).

66 EHRM, M.C. A. Bulgarije, 4 december 2003. Appl. No $39272 / 98$, Reports of Judgments and Decisions, 2003-X11, parr. 149-166.

67 EHRM, A t. Verenigd Koninkrijk, 23 september 1998 . Appl. No. 25599/94, Reports of Judgments and Decisions 1998 -VI, p. 2699, par. 22.

$68 \mathrm{EHRM}_{0}$ 2. and others t. Verenigd Koninkrijk, 10 mei 2001, Appl. No. 29392/95, Reports of Judgments and Decisions, 2001-V, par. 73-75.

69 EHRM, E. and others t Verenigd Koninkrijk, 26 november 2002, Appl. No. 33278/96, par 99" 100.

70 E/CN.4/2004/66, Towards an effective implenvertation of international norms to end violence against wamen. Report of the Special Rapporteur on violence against wamen, its Causes and consequences, Yakim Erturk, par. 47, en E/CN.4/2004/76, Report of the Special Rapporteur, Ms. Gabriela Rodriguez Pizarro, submitted pursuant to Commission on Human Rights resolution $2003 / 46$, par. 49 .

71 EHRM, Siliadin t. Frankrijk, Appl. No. 73316/01, 26 julli 2005, par 111-149.

72: Zaken ower vrouwenmishandeling in de priwé-sfeer zijn nog niet door het Hof behandeld, dus het is niet met zekerheid te zeggen in hoeverre het Hof de toets ook deze situaties toepast. Ela Grdinic; Application of the elements of torture and other forms of ill-treatment. as defined by the European Court and Commission of Human Rights, to the incldents of domestic violence, in: Hastings International and Comparative Law Review, Vol. $23(1999-2000)$, P. 217-260, p. 259

73 Comite tegen Marteling, supra noot 50, pat 7.

74. Comite tegen Aarteling. Supro noot 50 , par $2 \%$

75 Comité tegen Marteling, supra noot 50 , par. 26.

76 Comite tegen Marteling, supra noot 52. par. $7(c)$.

77 Copelors, supra noot 4 en noot 58 , met verdere verwilzingen.

78 inter Amerikanse Commissie voor de Rechten wan de Mens, Report No. 54/101, Case i2.05\% Maria da Penha Maia Fernandes t. Brazhlë, 16 april 200H, par. 8-24. 


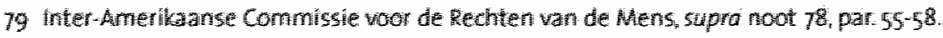

Bo Psisberkht no. $30 / 05$ van de Rapporteut inzake de nechten wan de wrouw van de IntezAmerikaanse Cormmissie soor de Rechten wan de Neris.

81 Comte inzake de Utbanning van Discriminatie van Wrowwen, Comm No. $2 / 2003$, A.t.t. Hongorije, 26 januari 2005 , in: NucM-Buffetin, jrg 30 (2005), pi. 470-480 met noot Ineke Boerefing.

82 Comite inzake de Uitbanning van Discriminatie van vouwwen, supra noot 24, p. $302-307$.

83. Comite inzake de utbainning van Discrimnatie wan Wrouwen, supra noot 8;, par. 9.3.

34. Interessant is te vermelden dat het Comite tegen Marteling Hongarije om informatte heeft gevragal over de maatregelen die de sta th theft getroffen raar aanleiding van deze uitsprabk. Zle CAT/C/HUN/Q/4, List of isswes to be considered during the exomination of the fourth periodic report of Hungary (CAT/C/5S/Add 10). De bespreking van het rapport vindt plats in novernber 2006, de verstagen van de zitting en de tandencommentaren zijn op dit moment nog niet gepubliceerd. 
